\title{
Denetimdeki Bedenler: Bikini Fitnessta Üretilen Kadınlık Kimliği
}

\author{
İrem KAVASOĞLU ${ }^{1 \dagger}$, Ayşe MACiT ${ }^{1}$ \\ ${ }^{1}$ Çukurova Üniversitesi Beden Eğitimi ve Spor Yüksekokulu, ORCID iD: 0000-0003-3969-1163. \\ ${ }^{2}$ Çukurova Üniversitesi Beden Eğitimi ve Spor Yüksekokulu, ORCID iD: 0000-0003-2229-3812.
}

\section{Öz}

Orijinal Makale

Vücut geliştirme ve fitness, geleneksel olarak erkeklikle ilişkilendirilen bir spordur. Bu sporun bir dalı olan bikini fitness ise, bedenin aşırı kaslı bir görünüme sahip olmadan kadınsı estetikle idealize edilmesi olarak yorumlanabilir. Bu spordaki kadınların deneyimleri üzerinden, hem toplumsal cinsiyet rejiminin yeniden inşasını hem de eril denetime meydan okumanın farklı formlarını analiz edebiliriz. Nitekim bu alandaki sporcular bir yandan ideal olarak kurgulanan kadın bedenine ulaşmaya çalışırlarken diğer yandan bikini giyme pratiği üzerinden eril tahakküme karşı bir tehdit oluşturmaktadırlar. $\mathrm{Bu}$ çalışma, bikini fitnessçı kadınların maruz kaldıkları cinsiyetçi/ayrımcı pratikleri, beden ve iktidar ilişkisi ile eril tahakküm bağlamında incelemeyi amaçlamaktadır. Nitel araştırma yöntemlerinden fenomenoloji deseninin kullanıldığ 1 bu araştırmada veriler görüşme tekniği ile toplanmıştır. Araştırma grubunu, iki antrenör, dört sporcu olmak üzere toplam altı kişi oluşturmuştur. Veriler içerik analizi yöntemi ile analiz edilmiştir. Bulgular, bikini fitnessın toplumsal cinsiyetlendirilmiş bir alan olduğunu ve bu alanda disipline edici iktidar pratiklerinin uygulandığını göstermektedir. Katılımcıların aileleri ve sosyal çevreleri, onların bikini giymesinden rahatsız olmuş ve erkek gibi kaslı olacaklarından endişe duymuşlardır. Sonuç olarak bikini fitnessın, bir yandan kadınların geleneksel kadınlık normlarını yeniden inşa etmesi nedeniyle baskıcı, diğer yandan beden üzerindeki eril denetimin kalıplarını yıkma özelliği nedeniyle güçlendirici bir pratik olduğu anlaşılmaktadır.

\section{Bodies in Control: Feminine Identity Produced in Bikini Fitness}

\begin{abstract}
Bodybuilding and fitness is a sport traditionally associated with masculinity. Bikini fitness is a branch of this sport, can be interpreted as idealizing feminine aesthetics without having an overly muscular appearance of the body. Through the experiences of women in this sport, we can analyze both the reconstruction of the gender regime and the different forms of challenging the masculine control. While the athletes in this area are trying to reach the idealized female body, on the other hand, the practice of wearing bikinis poses a threat against masculine domination. The aim o this study is to examine the sexist/discriminatory practices that bikini fitness women are exposed to in relation to body and power relations and masculine domination. Phenomenology was used in this research as qualitative research methods. Data were collected by interview method. A total of six participants, including two coaches and four athletes, participated in the study. Data were analyzed by the content analysis method. Findings show that bikini fitness is a gendered area and that disciplinary power practices are practiced in this area. The participants' families and social circles were disturbed by the fact that they were wearing bikinis and worried about being muscular as men. As a result, bikini fitness, on the one hand, represses the traditional feminine norms of women, on the other hand, is an empowering practice because of the ability to destroy the patterns of masculine control over the body. contributes to boosting young adults' confidence. Gender, income, hometown, and future vocational aspirations to practice in the same field as one's studies do not significantly predict overall career adaptability.
\end{abstract}

DOI: $10.30769 /$ usbd.425447

Anahtar kelimeler: eril tahakküm, disiplinci iktidar, bikini fitness.

\footnotetext{
*Bu çalışma, 10-12 Mayıs 2017 tarihinde Kırıkkale'de düzenlenen 10. Spor Bilimleri Öğrenci Kongresi’nde poster bildiri olarak sunulmuştur.

$\dagger$ Sorumlu Yazar E-mail: kavasogluirem@gmail.com
} 


\section{GíRIŞ}

Fiziksel bedenlerin toplumsal bedenlere dönüşmesinde en önemli etkenlerden biri toplumsal cinsiyettir. $\mathrm{Bu}$ bağlamda beden, toplumsal kontrolün somut olarak uygulandığ1 yer (User, 2010: 136-137) olarak görülmektedir. Kadın bedeni ise biyoloji ve fizyolojinin egemenliğindeki bir alan olarak müdahale edilmesi gereken, üzerinde müzakerelerin yapıldığ bir düzleme taşınmış durumdadır (Öztürk ve Koca, 2014). Çünkü kadın olmak, Judith Butler'ın da yazdığı üzere bir 'bela' olagelmistir. Tarihsel süreçte iktidar mekanizmaları, cinsiyet ve kadını mahrem üzerinden tanımlayarak bedeni denetim altına almak için tüm varoluş meselesini bu temel üzerine kurmuştur (Kaylı, 2009: 152).

Kadının, bedeni ile olan ilişkisi tarih boyunca değişime uğramış ve farklı fiziksel, sembolik, sosyokültürel, vb. kodlar altında ele alınmıştır. Yine tarih boyunca filozoflardan ressamlara, antropologlardan tıp dünyasına çeşitli başlıklar altında konu olan kadın bedeni, bugünün tüketim kültürünün en önemli odak noktalarından biri haline gelmiştir (Doğan, 2010). Beden, her gün medya ve popüler söylem tarafindan yeniden biçimlendirilmekte, ideal vücut ölçülerine sahip ikonlar her an kadınların arzularını canlı tutma üzere ortada salınmaktadırlar. Popüler söylemin ve medyanın sürekli canlı tuttuğu uyarıcılar yardımıyla kadın, kısıtlı bir beden tipine, ikon tarzı bir imaja ve dar güzellik çerçevesine sıkışıp kalmaktadır (İnceoğlu ve Kar, 2010: 69, 73). Tüketim kültüründe tüketilen bir nesne halini alan, kültürel, tıbbi ve medyatik söylemlerin normalize ve problematize ettiği ve tüketicilerin ulaşmayı arzuladığı “öteki” beden, daima kendi bedenlerinden daha ince bedendir (Dedeoğlu ve Savaşçı, 2005). Bu bağlamda tüketim toplumunda kadın için tasarlanan imaj, cinsel çekiciliği olan, zayıf ve güzel kavramları üzerinden inşa edilmektedir.

Alanyazında kadın bedenini ele alan pek çok çalışma mevcuttur. Bu çalışmalar, kadın bedeninin sosyal bir inşa olarak kurulması, tarihin eski dönemlerinden itibaren ve şuanki tüketim toplumunda kadın bedeninin denetimi ve beden üzerindeki tahakkümü, ideal kadın bedeninin, incelik, zayıflık, estetik ve güzellik gibi söylemleriyle kadınlara dayatılması, sağlıklı bedenin güzellik ve zayıflıkla ilişsilendirilmesi ve bunların kadınlar tarafından içselleştirilmesine bağlı olarak, idealize eden bu bedenlere ulaşma yolunda iktidarın nesnesi haline gelmelerine odaklanmaktadır (Bilgin, 2015; 2016; Dedeoğlu ve Savaşçı, 2005; Demez, 2012; Doğan, 2010; Ersöz, 2010; İnceoğlu ve Kar, 2010; Kesim ve Kar, 2010; Köse, 2011; Ozansoy, 2012; Timurturkan, 2009; User, 2010). Görüldüğ̈̈ gibi kadın bedeni toplumsal hayatın farklı kurumları aracılığıyla tahakküm altına alınmakta, bu tahakküme göre şekillendirilmekte ya da sınırlandırılmaktadır. Peki, yine toplum yaşamının somut/reel yaşamdan kopuk "ayrıcalıklı bir alan" olmayan, aksine sistematik ve kaçınılmaz bir biçimde toplumla bağlantılı bir alan olan sporda (Talimciler, 2015: 56) sporcu kadın bedeni üzerindeki tahakküm pratikleri nelerdir? Nitekim Koca'nın (2016) da altını çizdiği gibi, "spor alanını yaşayan da yaşatan da bedendir." (s. 24) ve "sporcu bedenin inşası, onun bedenselleşmesine ve toplumsal cinsiyetlendirilmesine hizmet eden pratikler aracılığıyla gerçekleşir." (s. 25). Bu araştırmada beden üzerindeki eril tahakküm mekanizmalarına başlı başına bikini giyme pratiği üzerinden meydan okuma özelliği taşıyan bikini fitness araştırma alanı olarak seçilmiştir. Çalışmada, bedene ve beden eylemelerine ilişkin çalışmalara odaklanması ve iktidarın gündelik yaşam içinde bedenler üzerinden kendini nasıl inşa ettiğini ve bununla 
çatş̧an icraların nasıl gerçekleştiğini anlamaya çalışması (Hacısoftaoğlu ve Bulgu, 2012) nedeniyle post yapısalcı feminizm ve Foucault'nun kavramsal araçları ile Bourdie'nun eril tahakküm kavramı referans alınmıştır.

\section{Kadın (Sporcu) Bedeni ve Tahakküm Pratikleri}

Herhangi bir ideoloji, gelenek, adet ancak öznelerin gündelik hayat pratiklerinde kendi bedenlerince deneyimlendiği ve normalleştiği oranda kabul edilmekte ve yerleşmektedir. Bu durumda oluşan/oluşturulan beden algısı bir çeşit ideolojiye işaret etmektedir (Topaloğlu, 2010). Başka bir anlatımla, beden ve beden üzerine uygulanan denetimin, disiplinin; kaynağını içinde bulunduğu toplumdan yani döneminin geçerli değerleri ve ideolojisinden aldığı söylenebilir (Demez, 2012). Bu noktada kadın sporcu bedenlerine yüklenen anlamların toplumsal cinsiyet ideolojisini yansıtması bakımından anlamlı olduğunu görürüz.

Bourdieu (2014) bedeni, toplumsal bir ürün (s.84) olarak değerlendirir ve Bourdieu'cü düşünüş, bedenin kendisini eril tahakküm uygulamalarının maddileşmiş yüzeyi sayar. Bedenin içi zaten toplumsal olanın uğultularıyla doludur. Bu bakış açısından düşünüldüğünde, gözden ve güçten düşürülmüş dişil beden, tahakkümcü düşünce ve uygulamaların bir ürünüdür (Köse, 2016). Dolayısıyla bikini fitness yapan kadınlar için bedenin denetlenmesi ve baskılanmasına yönelik olarak karşımıza çıkan uygulamaları, eril tahakkümün önemli göstergeleri olarak değerlendirebiliriz.

Foucault'ya göre beden, politik çatışmanın bir alanı olarak görüldüğü için, iktidar tarafından şekillendirilmektedir (Foucault, 2003'ten aktaran Hacısoftaoğlu, 2005: 11). Foucault iktidarı, belli kavram ve kuramlar içeren ve ürettiği doğrularla ifade bulan, söylemsel normlar, kurallar ve pratikler üzerinden işleyen bir alan olarak görür (Akgündüz, 2013). Bu bağlamda iktidar, bireylerin bedenleri üzerinde hakimiyetini çeşitli şekillerde sağlar (Topaloğlu, 2010).

Foucault, iktidar sorununun yeni baştan formule edilmesi gerektiğini düşünür çünkü Foucault'ya göre modern toplumda iktidar baskı kurma ve zorlama yoluyla değil; içselleştirilen bir gözetleme dizgesi gibi disiplinci iktidar şeklinde işlemektedir (Sarup, 2004: 103, 111). Modern (disiplinci) iktidar, tüm toplumsal ilişkiler boyunca iş başındadır. Bu yüzden Foucault (2014) bu yeni iktidarı biyo-iktidar olarak adlandırıyor (s.16). Negatif ve sınırlayıcı olan ve hükümranın yaşama hakkı üzerinde söz sahibi olmasıyla tanımlanan hukuksal-söylemsel modelin iktidar anlayışının tersine, bu yeni iktidar biçimi üretken, yaşamı desteklemeye, yaşamın sağladığı güçleri sınırlamaya değil arttırmaya yönelik, yani pozitiftir Aynı zamanda bu iktidar biçimi, bireyi kategorize ederek, bireyselliğiyle belirleyerek, kimliğine bağlayarak, ona hem kendisinin hem de başkalarının onda tanımak zorunda olduğu bir hakikat yasası dayatarak doğrudan gündelik yaşama müdahale eder (Foucault, 2014: 16, $63)$.

Foucault (2012), toplumsal bedeni ortaya çıkaran şeyin konsensus olmadığını, bizzat bireylerin bedenleri üzerindeki iktidarın maddiliği olduğunu vurgular (s. 39). O'na göre iktidarın bedeni artık denetim-baskı biçiminde değil, denetim-teşvik biçiminde kendini gösteren yeni bir kuşatması söz konusudur: "Çırılçıplak soyun... ama zayıf, güzel, bronz tenli 
ol!" (s. 40) söyleminde olduğu gibi, modern özne günümüzde; bedeni çalıştıran, davranışa nufüz eden, arzu ve zevkle iç içe giren iktidara (s. 49) gönüllü olarak itaat etmektedir. Bu bağlamda bikini fitnessta değer gören ideal beden modern iktidar tarafından şekillenmiş ve alanın öznelerinin bedenlerini kuşatmış olabilir.

Feminist kuram içinde Foucault'dan özellikle etkilenen post yapısalcı feminizm bedene ve beden eylemelerine ilişkin çalışmalara odaklanmıştır. Bir eylemeyi birbiriyle çatı̧san anlamlarıyla analiz etmek için önemli kavramsal araçlar sunan post yapısalcı feminizm, bu kavramsal araçlar aracılığıyla iktidarın gündelik yaşam içinde bedenler üzerinden kendini nasıl inşa ettiğini ve bununla çatışan icraların nasıl gerçekleştiğini anlamaya çalışmıştır (Hacisoftaoğlu ve Bulgu, 2012). Foucault'nun bedensel üretim teknolojileri nosyonu düşünüldüğünde, spor da merkezi özelliği disiplin ve kontrol olan bir kurum olarak ele alınabilir. Çünkü spor, ataerkil kapitalizmin ihtiyaçları doğrultusunda bedeni biçimlendiren, disipline eden bilgiler ve pratikler bütünüdür (Koca ve Bulgu, 2005). Fakat sporu ve atletik performansı erkek-merkezli yarışma, hiyerarşi ve saldırganlık özellikleriyle tanımlayan kendinden önceki feministlerin aksine, son dönem post-yapısalcı feminist araştırmacılar sporla açığa çıkan çelişkileri, arzuları ve hazları sahiplenmeye ve sporu sadece baskı ya da sadece direnme ikiliğiyle değil, her ikisinin birlikteliğiyle bakmaya başlamıştır (Öztürk, 2016: 51). $\mathrm{Bu}$ araştırmada bikini fitness yapan kadınlar hem kültürel olarak erkeklikle ilişkilendirilen bir alanda var olma, hem de beden üzerindeki denetimin sınırlarını aşan bir eylem gerçekleştirme -bikini giyme- gibi bağlamlarda özgürleşme deneyimi yaşayabilecekleri gibi, alanın bedeni ideal olarak kurgulayan yapısında kadınsı estetiğin korunması vurgusunu ön plana çıkarması ve toplumsal cinsiyet rejimini yeniden inşa etmesi bağlamında baskıcı deneyimler yaşayabilirler.

\section{YÖNTEM}

Araştırma Modeli: $\mathrm{Bu}$ araştırmada nitel araştırma desenlerinden fenomenolojiden faydalanılmıştır. Fenomenoloji; tek tek insanların bakış açılarından bakarak onların bireysel anlam yapılarını, niyetlerini anlamaya çalışmaktır (Mayring, 2011: 110). Katılımcıların bikini fitness deneyimlerini açığa çıkarmak, bu alanda bedenlerini nasıl anlamlardırdıklarını, bu bedenin iktidar araçları ve eril tahakküm bağlamında nasıl şekillendiğini analiz etmek için fenomenoloji deseni kullanılmıştır.

Araştırma Grubu: Araştırmanın katılımcıları amaçlı örnekleme yöntemlerinden ölçüt örnekleme yöntemine göre seçilmiş (Patton, 2014: 46) ve araştırmada seçilmiş soruları aydınlığa kavuşturacak, zengin bilgi sunacak kişiler araştırmaya dahil edilmiş̧ir Bu bağlamda araştırmanın katılımcılarını araştırmaya ulusal ve uluslararası yarışmalarda deneyimleri olan en az 2 yll boyunca bikini fitness yapmış 4 sporcu ve en az 5 yıl deneyimli 2 bikini fitness antrenörü olmak üzere toplam 6 kişi oluşturmaktadır. Yaşları 22 ile 31 arasında değişen katılımcıların tamamı bikini fitness dalında ulusal/uluslararası yarışmalara katılııı milli sporculardır (Tablo 1). 
Tablo 1: Katılımcıların demografik bilgileri

\begin{tabular}{|c|c|c|c|c|c|c|}
\hline Kod İsim & $\begin{array}{l}\text { Alandaki } \\
\text { Kimliği }\end{array}$ & Yaş & Deneyim & Eğitim & $\begin{array}{c}\text { Ulusal } \\
\text { Yarışmalar }\end{array}$ & $\begin{array}{l}\text { Uluslararası } \\
\text { Yarışmalar }\end{array}$ \\
\hline Tuğçe & $\begin{array}{l}\text { Antrenör/ } \\
\text { Sporcu }\end{array}$ & 30 & $15 \mathrm{y} 1 \mathrm{l}$ & $\begin{array}{l}\text { Üniversite } \\
\text { mezunu }\end{array}$ & $\begin{array}{c}\text { Türkiye } \\
\text { Şampiyonaları }\end{array}$ & $\begin{array}{c}\text { Dünya ve Avrupa } \\
\text { Şmp. }\end{array}$ \\
\hline İpek & $\begin{array}{l}\text { Antrenör/ } \\
\text { Sporcu }\end{array}$ & 31 & $15 \mathrm{y} 1 \mathrm{l}$ & $\begin{array}{l}\text { Üniversite } \\
\text { mezunu }\end{array}$ & $\begin{array}{c}\text { Türkiye } \\
\text { Şampiyonaları }\end{array}$ & $\begin{array}{c}\text { Avrupa } \\
\text { Şampiyonası }\end{array}$ \\
\hline Yasemin & Sporcu & 22 & 5 yil & Ünv. Öğrencisi & $\begin{array}{c}\text { Türkiye } \\
\text { Şampiyonaları }\end{array}$ & $\begin{array}{c}\text { Dünya } \\
\text { Şampiyonası }\end{array}$ \\
\hline Roza & Sporcu & 23 & 3 y1l & Ünv. Öğrencisi & $\begin{array}{c}\text { Türkiye } \\
\text { Şampiyonaları }\end{array}$ & $\begin{array}{c}\text { Avrupa } \\
\text { Şampiyonası }\end{array}$ \\
\hline Buket & Sporcu & 22 & 5 y1l & Ünv. Öğrencisi & $\begin{array}{c}\text { Türkiye } \\
\text { Şampiyonaları }\end{array}$ & $\begin{array}{c}\text { Dünya } \\
\text { Şampiyonası }\end{array}$ \\
\hline Asya & Sporcu & 24 & 3,5 yil & Ünv. Öğrencisi & $\begin{array}{c}\text { Türkiye } \\
\text { Şampiyonaları }\end{array}$ & $\begin{array}{c}\text { Avrupa } \\
\text { Şampiyonası }\end{array}$ \\
\hline
\end{tabular}

Veri Toplama: Bireysel görüşme yöntemi kişilerin deneyimleri, duyguları ve bilgileri ile ilgili doğrudan alıntılar yapılabilmesine olanak vermektedir (Patton, 2014: 4). Araştımanın verileri görüşme esnasında yeni sorular sorulmasına firsat tanıması ve esnek olması nedeniyle yarı yapılandırılmış görüşme tekniği kullanılmıştır. Derinlemesine görüşme bir veri tekniği olarak, açık uçlu soruların sorulması, dinlenmesi, cevapların kaydedilmesi ve ilişkili ilave sorularla araştırma konusunun detaylı bir şekilde incelenmesini mümkün k1lar (Kümbetoğlu, 2015: 71).

Araştırma soruları araştırmanın amacı ve kavramsal çerçevesinden hareketle oluşturulmuştur. Katılımcıların bu branşı tercih etme nedenleri, kendilerini destekleyen/motive eden unsurlarların neler olduğuna dair genel sorularla başlanmıştır. Daha sonra, bu alanda kadın olma deneyimleri hakkındaki görüşleri, ilgilendikleri spor dalı nedeniyle çevrelerinden (aile, arkadaş, partner, komşular vs.) aldıkları tepkiler, bunlar karşısında kendilerinin nasıl hissettiği ve bunları nasıl aştığı gibi sorular sorulmuştur. Örneğin, Bikini fitnessta kadın sporcu/antrenör olmanın sizin için nasıl bir anlamı var? Çevrenizdekiler (aile, komşu, arkadaş, sevgili vs) bikini fitness yapmanızı nasıl karşıllyor? Aldığınız olumlu ve olumsuz tepkilere örnek verir misiniz? Bu tepkiler karşısında nasıl bir karşıllk veriyorsunuz? Size göre ideal bir bikini fitnessçı bedeni nasıl olmalıdır?

Görüşmeler katılımcıların istekleri doğrultusunda kampüs ya da spor salonlarında yapılmıştır. 25 ile 75 dakika arasında süren görüşmelerden önce katılımcılara onam formu imzalatışmış, ses kaydı açıldıktan sonra araştırmaya gönüllü katılmayı kabul edip etmedikleri tekrar sorulmuş ve gönüllü katıldıklarına dair onay alınmıştır. İmzalamalarını istediğimiz onam formunda araştırmanın amacı, verilerin hangi amaçla ve nerelerde kullanılacağı, görüşmenin ortalama ne kadar süreceği hakkında bilgiler yer almaktadır. Ayrıca yanıtlamak istemedikleri sorular varsa bunları geçebilecekleri ve istedikleri zaman görüşmeyi sonlandırabileceklerine dair açıklamalar bulunmaktadır. Araştırma için Çukurova Üniversitesi Girişimsel Olmayan Klinik Araştırmalar Etik Kurulundan onay alınmıştır. Görüşmelerden sonra ham veriler tüm katılımcılarla paylaşılmış (mail yoluyla) kullanılmasını istemedikleri yerler olursa bunların analizlerde kullanılmayacağı bilgisi verilmiştir. 
Veri Analizi: Araştırmanın verileri içerik analizi yöntemiyle analiz edilmiştir. Yapılan görüşmelerin ardından ses kayıtları bilgisayara aktarılmış ve ham veriler satır satır kenarına notlar alınarak okunmuştur. Kategorileri belirlemek için, araştırmanın amacı doğrultusunda ham veriler tekrar okunmuş ve kodlar çıkarılmıştır. Bu kodlar kod defterine işlenmiş ve bağlantılı olan kodlar alt alta getirilerek kategorilere ulaşılmıştır. İki ayrı araştırmacı tarafından gerçekleştirilen bu süreç sonucunda, fikir birliğine varılan kategoriler tema haline getirilmiştir. Böylelikle araştırmanın güvenirlik ve inandırıcılığı sağlamak için araştırmacı üçlemesi tekniği kullanılmış veriler iki araştırmacı tarafından analiz edilmiştir (Patton, 2014: 247). Bunun dışında analize kadar olan süreç detaylı olarak açıklanmış, elde edilen bulgular verilerle/doğrudan alıntılarla desteklenmiştir.

\section{BULGULAR VE TARTIŞMA}

Araştırmanın bulguları 4 tema altında toplanmıştır:

1. Beden üzerindeki eril tahakküm pratikleri: “...Sen erkek gibi niye kas yapıyorsun, hiç yakışır mı böyle bir şey; bikini giyiyorsun hani çok ayıp..."

2. Eril tahakkümün iki yüzlü anlamları: "Bikini mi, ya nasll giyeceksin? / Bir gece benimle birlikte olur musun?”

3. Belalı bedenler: "Hem fit olsun, hem bayan olsun, hem kibar olsun"

4. Var olma ve mücadele stratejileri: "Özel yaşantımızda her bayan gibi özenliydik ve bunu koruduk, kaybetmedik, nasıl kadınsak öyle kaldık”

1. Beden üzerindeki eril tahakküm pratikleri: “...Sen erkek gibi niye kas yapıyorsun, hiç yakışır mı böyle bir şey; bikini giyiyorsun hani çok ayıp...”

$\mathrm{Bu}$ temada, bikini fitness yapan beden üzerindeki tahakküm pratikleri, alanın toplumsal cinsiyetlendirilmiş yapısı ve cinsiyetçi pratikler açıklanmaya çalışılmıştır. Katılımcılar, toplumsal algıda, vücut geliştirme ve fitnessın iri yarı olmak, çok kaslı ve erkek gibi olmak anlamına geldiğini ve bu nedenle genel olarak sporla özelde ise bikini fitness ile ilgilenmeleri nedeniyle aile ve sosyal çevrelerinden, cinsiyetçi ve motivasyonlarını kırıcı yorumlar aldıklarını belirtmişlerdir. Örneğin, Tuğçe yakın çevresinden "Yani bu kadar gerek var mıydı?; Niye bu kadar arttırdın (kas oranını)? Neden sporcu oldun? Spora gerek var mı? Oturup ders çalışıp başka bir şey olaydın." gibi tepkiler alırken Asya "Sen ne güzel ögretmenlik okuyosun. İşte bayan ögretmenlik yapar, evinden işine gider. Salona gitme. Salona gidip, işte niye 5 gün antrenman yapıyosun? Boş yere zamanını öldürüyosun, kendini yoruyosun gibisinden. Erkek arkadaşım da böyle söylüyor. Yani çevremden söyleyenler de var; işte sen artık hedeflerine ulaştın, yapma, boşver, sınava hazırlan, kendini yorma” gibi yorumlar almışlardır. Yasemin ise cinsiyeti nedeniyle alanda yaşadığı sorunların sebeplerini şu şekilde anlatmıştır:

"Tamamen ataerkil bir toplum olmamız. Kadınları hani öyle bir farklı bir yere koyuyorlar ki, hani bunları kesinlikle yapamaz. Isste sınır çiziyorlar. Onlar bu sınırı aştıkları zaman işte size de anormal bakıyorlar yani. Çünkü kendi kalıpları var, bizi de o kalıbın içine 
sıklştırmaya çalışıyorlar. Kendi istedikleri gibi bir şey olmamızı istiyorlar, dışarı çıkınca bize farklı bir damgalama, muamele oluyor." (Yasemin, sporcu).

Katılımcılardan Tuğçe, Buket ve Roza'nın da altını çizdiği gibi toplum, onlardan geleneksel kadınlık rollerini tesis edebilecekleri spor branşlarına yönelmelerini bekleyerek, bedenlerini tahakküm altına almaktadır. Nitekim kadınlara uygun sporlar toplumsal cinsiyet kalıp yargılarına göre ve kadın bedeninin estetikliği temel alınarak şekillenir. Örneğin dünyada ve ülkemizde bedensel temas ve yüzyüze mücadeleler içermeyen buz pateni, tenis, yüzme, cimnastik gibi hafif ve estetik branşlar kadınlar için uygun görülürken; boks, halter, güreş, futbol gibi branşlar kadınlar için uygun görülmemiştir (Reimer ve Visio, 2003; Matteo, 1986). Bu durum spor ortamlarında kadınların özgürce seçim yapmalarının önünü kapadığı için bir tahakküm unsurudur hem de normatif var oluşa yol açtığ için tektipleştirici bir iktidar pratiği olarak yorumlanabilir.

Aşağıdaki alıntıdan kadınlar için uygun görülen spor dallarının toplumsal cinsiyet kalıp yargılarına göre çizildiği anlaşılmaktadır.

"Yani kız olduğum için, aslında o anda bikini fitnesstan caydırmak için öyle şeyler (başka branş yok mu) söylüyorlar. Ama mesela tutup futbol yapsa, aman klzsin ya ne futbolu diyorlar, atletizm, offf bir kıza göre çok işte zor, bir spor atletizm falan ne gereği var ya. Çünkü onda da kas kütlesi artıyor, atletizmde de işte vücudun bozulur gibisinden şeyler tarzında. Hani onlarda da öyle şeyler olur ne olabilirdi mesela cimnastik olabilirdi tenis olabilirdi" (Buket, sporcu).

"Kadınlara yüzmeyi bile yakıştırmıyorlar çünkü sırtları genişliyor, bunları da istemiyorlar işte pilates, cimnastik, yürüyüş bunun gibi basit, basit demeyim de, hani vücuda çok etkisi olmayan sporları uzun dönemde etkisi olan sporlar istiyorlar" (Roza, sporcu).

Yukarıdaki alıntılardan da görüldüğü gibi kadınların spor deneyimleri toplumsal cinsiyet kalıp yargılarına sıkı sıkıya bağlıdır. Chimot ve Louveau (2010), örgütlü sporun erkekler kadar kadınlara açık olmasına rağmen, toplumsal cinsiyet hattı boyunca farklı spor arasında hâlâ net bir bölünme/ayrım olduğunun altını çizer. Nitekim toplumsal cinsiyet rejimi, kadınların spor deneyimlerini erkeklerin çizdiği sınırlarla tanımlanmakta ve bu sınırı ihlâl etmeyen sporları onaylanmaktadır. Alanyazındaki pek çok araştırma, kadın ve erkeklerin spor deneyimlerinin geleneksel cinsiyet rollerine göre şekillendiğini ve cinsiyetler -özellikle kadınlar- için uygun görülen ve uygun görülmeyen sporların var olduğunu göstermektedir (Chalabaev ve diğ., 2013; Koivula, 2001; Matteo 1986; Reimer \& Visio, 2003). Böylece cinsiyet normlarının dışındaki spor deneyimleri üzerinde toplumsal bariyerler kurması, ayrımcılık ve eşitsizlik üretmesi nedeniyle (Kavasoğlu ve Yaşar, 2016) spor, kadınlar üzerinde baskı kuran bir eylem alanına dönüşebilir.

Katılımcılar, bikini fitness branşının bikini giymeyi zorunlu kılması nedeniyle sosyal çevrelerinin ve ailelerinin bu branşa karşı çıktıklarının altını çizmiştir. Katılımcıların bikini giymelerini ciddi bir sorun hâline getiren ve bu nedenle bikini fitness yapan beden üzerinde 
kolektif bir kontrol ve baskı uygulayan bu kişiler, katılımcılarımızın bikini fitness deneyimlerini sınırlandırmışlardır. Örneğin Yasemin ve Buket'in aileleri tarafından antrenmanlara gitmelerini engellemeye varan (Buket'in annesi) tepkiler geliştirdiği anlaşılmaktadır. Örneğin Yasemin ile yakın arkadaş olan Buket bu durumu "Ailelerimiz hiç hiç destek olmadl. İkimizin (Buket ve Yasemin) ailesi de hiçbir şekilde destek olmadl, hatta tam aksine oldular, köstek oldular yani... Bikini fitness olayına daha çok karşı oluyorlardı, uygun bir branş olduğunu düşünmüyorlardl, kendilerine biraz tersti. Denizde giyebilirdik ama hani ailemizin yanında giyebilirdik, neden yarışma formatında giyiyoruz, bu tartışma oldu" sözleriyle açıklarken, akrabaları ile aile üyelerinin bir araya gelip bikini fitnessı kendisi için uygun bulmadıklarını Yasemin aşağıdaki sözleriyle ifade etmiştir:

“İlk başlarda hiç ailem istemiyordu, hatta bir dönem gizli yaptım ... Çünkü hani giydiğimiz kıyafet bizim bikini orada ama buna mecburduk. Çünkü bizim kaslarımıza baklyorlardı ve bize baktıkları niyet kesinlikle hani başka bir niyet değildi ve zaten onların bizi gördükleri, yani gören kişiler sadece hakemlerdi, bize puanımızı veren...Çünkü işte ben bir kadınım hani, hem çok önce kas oranına şey yapalım; fitness deyince akla direkt işte kas yapacaksın, işte sen erkek gibi niye kas yapıyorsun, hiç yakışır mı böyle bir şey. İşte bikini giyiyorsun hani çok ayıp anlamında yakıştırmalar yaptılar böyle, ailemden hepsi oturdular beni karşılarına alıp ağlatana kadar bana bir sürü şey söylediler işte” (Yasemin, sporcu).

Kadın bedeninin ve cinselliğinin düzenleme ve denetleme yöntemleriyle ataerkil rejim için namus kodları temelinde itaatkârlaştırılması, Foucault'un iktidar tanımlamalarıyla sorunsallaştırıl-abilir- (Kalav, 2015: 3). Buket ve Yasemin'in aileleri, çevrenin de gözetim yoluyla kurduğu baskıyı göz önünde bulundurarak, bikini giymeyi kızları için uygun/normal bulmamışlardır. $\mathrm{Bu}$ durum Buket'in annesinin Buket'i fitnesstan vazgeçirme ve Buket'in bedenini itaatkâr bir beden haline getirme çabalarına nasıl eklemlendiğini aşağıdaki alıntıdan görmek mümkündür:

“Annem izin vermiyordu diyet yapmama, döner falan getiriyordu bana (gülüşmeler), ondan sonra iki hafta boyunca falan antremana göndermedi beni, bildiğiniz kapıyı üzerime kilitledi. Böyle şeyler yaşadik, gitmeyeceksin dedi, para vermedi, yol param yoktu. Ondan sonra işte Yasemin geldi, annem işte sinirlendi falan annem tam bana vuracă̆l zaman Yasemin önüme atlamıştı, öyle durumlar oldu. Ondan sonra ben pencereden işte spor çantamı çıkartıyorum, kapıdan çıkmaya çalışıyordum hani çünkü kapıdan çıkarken spor çantası ile beraber çıkamam. Öyle şeyler yaşadım ondan sonra annem bunu çaktı ama kapıyı kitleyip gidiyordu mesela diyordu ki Yasemin 'le sana döner getirecem diyordu kapıyı kilitliyordu üzerimize öyle çıkıyordu, inanmıyordu. Iki hafta böyle geçti ve benim için, birazcık bir kayba uğradım ben form konusunda, antrenman yapamadım ve tam yarışma dönemim” (Buket, sporcu).

Buket'in annesi, eril tahakküm üzerine kurulu bir kadın beden inşası ve bu bedenin modern iktidar araçlarının da etkisiyle oluşturulan norma göre inşa edilmesini içselleştirmiş görünmektedir. Nitekim yaşam temelinde hareket eden biyo-iktidar, insanları normlara uymaya zorlayarak ve onları normalleştirerek bir normalizasyon toplumu oluşturur (Foucault, 2014: 16-18). Bedenin normalleştirilmesi ise, toplumun eril kodlarına göre işlediği için (zarif, 
estetik, güzel, alımlı vb.), Buket'in annesi Buket'in inşa edeceği bedeni normdan sapma olarak algılayıp endişelenmekte ve Buket'in bedeni üzerinde tahakküm uygulamaktadır. Burada eril tahakkümün anne dolayımıyla gerçekleştiğini görürüz. Bununla birlikte, yol parası vermemesi, diyetini bozması, odaya kilitlemesi (kapatma) gibi annenin yaptığı tüm eylemleri Buket'i sslah etme/terbiye etmeye yönelik iktidar pratikleri olarak okunabilir.

Örneğin yarışmalara hazırlanmak amacıyla antrenmanlarına düzenli olarak devam eden Asya erkek arkadaşının bikini giymesine ve yarışmalara katılmasına izin vermediğini "erkek arkadaşım zaten şu anda izin vermiyor yani yarışmalara da gitmemi istemiyor. Bikini giyme konusunda çok ısrarcı, giymemi istemiyor... videoları genelde önden çekiyorum (gülerek) arkadan fotoğraf istemiyo yani sırtını açma, göbeğini açma zaten yarışma yasak o şekilde” şeklinde açıklamış ve bunu kıskançlık olarak değerlendirmiştir. Şu an kendisini yarışma için yeterli hissetmediğinden dolayı sessiz kaldığını fakat "çok iyi olsam giderim yani dinlemem" sözlerinden yarışmalara katılma kararını formunu hazır hissettiğinde, kendi bağımsız kararıyla vereceği anlaşılmaktadır. Tam da bu nokta, sporun özgürleştirici yönüne güzel bir örnek teşkil edebilir.

Ataerkil ideoloji kadın bedeni üzerinde iktidar kurarken ve kadın bedenini şekillendirmeye çalışırken, en çok kıyafetler üzerinden hareket ettiği (Kula Demir ve Yiğit, 2013) söylenebilir. Araştırmamızın bulgularında görüldüğü gibi, sporcuların aileleri kız çocuklarının bikini giymesinden rahatsız olmuş ve onlara baskı uygulamışlardır. Ailelerinin katı yaklaşımlarının çevre ile yakından ilgisi olduğunun altını çizen katılımcılar, el alem ne der? sorgusunun onlar için önemli bir etkisi olduğunu düşünmektedir. Örneğin Yasemin, akraba ve komşularının ailesini nasıl etkilediğini "Çevre hani çok şaşırlyorlard, bir kere çok fazla yakıştırma yapıyorlardı. Siz bunlar giyiyorsunuz, ben rahat edemem, bir de hep şundan mesela kendilerinden örnek veriyorlar, ben olsam yapamazdım, kendileriyle klyaslayarak siz nasıl rahat ediyorsunuz, bu sekilde böyle dolduruyorlardı" sözleriyle açıklamıştır. Buket ise “... (klz) arkadaşlarım hep şey diyordu, işte bikini mi ya nasıl giyeceksin, işte ileride erkek arkadaşın olduğu zaman nasıl tepki verir, işste ay bilmiyorum ya ben giymem, ben yapmam falan ay utanmiyor musun hiç falan gibisinden çok fazla tepki geldi. Erkekler de hani daha kaba işte ben sevgilime giydirmem diye tepki veriyor ya da ben ben sevgilime yaptırmam aman benim sevgilim olsa ben ayrllırım gibisinden çok tepkiler fazla oldu” şeklindeki açıklamalarıyla beden üzerindeki eril denetimin hem kadınlar hem de erkekler tarafından oluşturulduğuna işaret eder.

Roza, "ĕger erkek olsaydım, sponsor bulabilirdim örnek veriyorum. Çünkü biz bir yere başvuru yaptı, belediyeye yaptı, bikini giyildiğini duyunca vermediler vazgeçtiler. Ama erkek olsaydım ĕger, o slip mayoyu giysem bile verilerdi ki fazlasını bile verirlerdi” diyerek Yasemin ise "işte erkek mesela benim erkek kardeşim yapsa sorun olmaz hatta desteklerler ama kadın olduğum için işte bazı mahrem yerlerimi gösteriyormuşçasına muamele gördük”" firsatlardan yararlanma ve spor yaşantılarının desteklenmesi boyutunda dahi eşitsizlik yaşadıklarını ortaya koymuştur.

Foucault (2012) iktidarın, bireylerin tohumuna kadar ulaştığı, bedenlerine eriştiği, hâl ve tavırlarına, söylemlerine, öğrenimlerine, gündelik yaşamlarına sindiği kılcal var olma biçimini 
düşündügünü söylerek (s.21) bizi toplumsal bedenin denetimi ve disipline edilmesinde makro yapılardan mikro yapılarına kadar sızan iktidar ilişkilerini düşünmeye sevk eder. Roza'nın deneyimleri hem kamusal alanda (belediye) hem özel alanda (ev) eril iktidarın tüm kurumlara sirayet etmiş; tek ve merkezî bir biçimde değil, her yerde ve çok boyutlu olarak karşımıza çıkabilek bir yapıda olduğunu anlamamızı sağlar. Bunun yanı sıra, toplumsal gerçekliğin farklı öznelliklerden oluştuğu ve bu nedenle farklı öznelliklerin olabileceğini (Koca, 2006) savunan postyapısalcı feminizminin aksine, Roza'nın deneyimleri kadın erkek ikili karşıtlığında, kadının özne konumunda olan erkeğe göre daha değersiz olarak konumlandığını doğrular niteliktedir. Bunun yanı sıra, beden üzerindeki tahakkümün çifte standartlı yapıda olduğunu ve erkek bedeninin özgürlüğü lehine işleyen; kadın bedeninin baskılanması üzerine kurulu yapısını görürüz. Hâlbuki toplumsal cinsiyette hakkaniyet; kaynaklara ve faydalara erişimde de adil ve hakkaniyetli davranılmasını gerektirir ve kadınların spor ve fiziksel aktiviteye katılımını arttırmak için toplumsal cinsiyet hakkaniyetli programlar geliştirmek (Koca, Öztürk ve Arslan, 2012: 11) ve bunu spor politikalarının içine nufüz eden bir bakış açısıyla uygulamak son derece önemlidir.

Katılımcılar hem sporcu hem de sporcu olmayan yakın çevrelerindeki erkek arkadaşları tarafindan erkeğin daha güçlü olduğunun (!) ispatına yönelik benzer cinsiyetçi deneyimler yaşamışlardır. Alandaki tahakküm ilişkilerini görmemizi sağlayan bu deneyimler çoğunlukla erkeklerin kendi güçleri ile kadınların güçlerini kıyaslama yoluyla kurulmuştur:

"Karın kaslarını kıyaslıyorlardı ve işte kaç kilo ă̆ırlık kaldırıyorsun? Bunda kaç kilo yapıyorsun? Kaç basıyorsun? Bunlart söylüyorlardl, ben de söylüyordum işte, kendileriyle karşılaştırlyorlardı öyle şeyler oluyordu” (Roza, sporcu).

Genellikle güce dayalı olduğu için bilek güreşi yapma teklifinde bulunan erkekler, yenildikten sonra bu yenilgilerini meşrulaştıracak söylemler üretmeyi ihmal etmemişlerdir. Örneğin "genelde hadi gel bilek güreşi yapalım, beni yener misin, yenebilir misin falan, yendiklerim oldu tabii” diyen Asya'ya ek olarak Buket'in bilek güreşinde bölümünden (BESYO) yendiği bir erkeğin sözleri "ya bütün gücümü uygulamadım şeyi vardı her zaman onun haricinde ya işte kız diye şey yapmadım” şeklinde olmuştur. Yasemin'in ise kaldırdığı ağırlık karşısında salondaki erkeklerden aldığı tebrik cinsiyetçi öğelerle doludur:

"Birkaç defa ă̆ırlık kaldırınca ooo ne güzel erkek gibi kaldırıyorsun, işte biz böyle kaldıramıyoruz ya da işte sizin neyinize bunu kaldırmak falan” (Yasemin, sporcu).

Görüştüğümüz sporculara kıyasla daha kaslı bir bedene sahip olan antrenör Tuğçe, salondaki erkek üyelerin kendisini gördükten sonra, cinsiyetçi kıyaslamalara bağlı olarak sik sik sakatlanmaları nedeniyle salonun daha sakin saatlerinde antrenman yaptığına değinmiştir:

"Erkekler benim vücudum gibi olmak istiyorlar ... Antremana girsem aynı hareketi yapmaya çalışan yüzlerce kişi olacak, o yüzden daha sakin saatlerde giriyorum sakatlanmasınlar diye (gülüşmeler). Ben erkek olmama rağmen onu kaldıramıyorsam ölürüm diyor yani (gülüşmeler). Kaldıramıyorlar, sakatlanıyorlar. Yani şöyle söyleyeyim kendi performansının \% 10 üzerine çıkmaya çalışıyor ki, bir hafta yatıyor 
ya da hastanelik oluyor. Hastanelik olan kişimiz de var (gülüşmeler)" (Tuğçe, antrenör).

İpek'in sözlerinden, eril tahakkümün inşasını, iktidarını fiziksel üstünlüğü ispatı yoluyla kurmaya çalışan erkeklerin, kadınlar tarafından yenilgiye uğramalarını, erkek iktidarının sekteye uğraması olarak algılandığını düşünebiliriz:

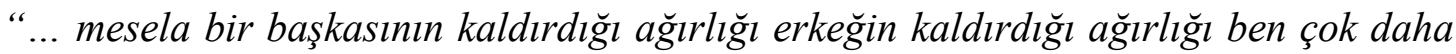
rahat kaldırabiliyorum. Ya da zorlanıp kaldıramadiğını ben çok rahat kaldırabiliyorum. Bu da onlarda şaşkınlık uyandırıyor ve bu yüzden spor salonunu bırakan çok insan oldu, moral bozukluğu yüzünden. Benim şu anki gittiğim spor salonlarında, apar topar adamın kıyafetini giyip çekip gittiğini, sonradan o kızı biz gördüğ̈̈müzde antrenman yapamıyoruz deyip de şikâyet aldı̆̆ımı da biliyorum. Çok yani ben de hiç bilmiyordum, çok şey oldu tuhaf oldu ama böyle şeyler kesinlikle oluyor" (Ipek, antrenör).

Kavasoğlu ve Yaşar'ın (2016) araştırma bulguları erkeklerin, hemen her firsatta kadın sporcularla (bilardo, boks, güreş ve futbolda) maç yapmak istedikleri katılımcılar tarafından vurgulanmış ve erkeklerin bu meydan okumayı kaybetme durumunu hazmedemeyip sinirlendikleri ortaya çıkmıştır. Çünkü erkeklerin üstünlük kurma mücadelesinin kadınlardan daha güçlü olduklarını ispatlamaları iktidarı inşa etmenin temel koşullarından biridir. Benzer şekilde bikini fitnessta da, güç ispatı yoluyla erkekliklerini kurma ve sürdürme yolunu seçen erkekler olduğu görülmektedir. Buket'in aşağıdaki alıntısı ise hem kadınların vücut geliştirme ve fitnessta ikincil olarak konumlandırılmalarına hem de erkeklerin kendi aralarında inşa ettikleri iktidar ilişkilerine güzel bir örnektir:

"Spor salonunda 20 kiloyla bench hani göğüs hareketi vardl, onu yapamayan erkekler oluyordu işte spor salonunda çalıştı̆̆ım zaman, patron beni çağırıyordu ben o zaman 40 kilo yapıyorum, işte gel şurda 3-4 tane bir tekrar yap falan diyorlard, yaptıktan sonra işte şakalaşıyorlardı aralarında, ya sen iste 20 kilo kaldıramıyorsun kız 40 kiloyu kaldırıyor gibisinden bakış açıları oluyordu” (Buket, sporcu).

Karaçam ve Koca'nın (2014) da belirttiği gibi vücut geliştirme hem sayısal hem de kültürel olarak erkeklerin katılım gösterdiği bir sosyal alandır. Bu alandaki erkekler arasında, beden sermayesi ve alanda sergilenen pratiklere dayanan bir yarış ve kıyas gerçekleşmektedir (örneğin kaç kiloyla bench basıyorsun?). Erkekliklere dair inşa ve yeniden üretimin incelenmesini mümkün kılan bu söylem ve pratikler erkeklerin arasında gerçekleşen rekabeti de göstermektedir (Karaçam, 2015: 69). Yukarıdaki alıntıda çeken nokta bu rekabetin erkekler arasında değil bir kadın ile gerçekleşmesidir ki Buket'in kendisinden daha fazla ağırlık kaldırdığı erkeğe dair yapılan şakalaşmalar aslında alanda marjinalleştirilen bu erkeğin diğer erkekler tarafından aşağılanmasına bir örnektir. Aynı zamanda kadınların kaldırdıkları ağırlıklar üzerinden ya da bilek güreşi yapma teklifi üzerinden kurulan bu karşılaştırma ve kıyaslamalar, kasın ve gücün erkeklikle ilişkilendirilmesi fikri ile yakından ilişkilidir. 
Toplumsal mekân toplumsal bir üründür ve bu şekilde üretilen mekân, düşünceye olduğu kadar eyleme de aygıt olarak hizmet ettiğinden, bir üretim aracı olmanın yanında, bir denetim, dolayısıyla tahakküm ve güç aracıdır (Lefebvre, 2016: 56). Mekânın kullanımını iktidar ilişkilerinden bağımsız düşünemeyeceğimizi anımsatan Yasemin'in sözleri, salonun çeperlerine sıkışan kadınlar ile salonun merkezine yayılan erkeklerin konumuna ve bu mekândaki bakışların baskı kurucu/rahatsız edici boyutuna işaret eder:

“...ben bazen rahatsız olacă̆ımı düşünüp hiç başta ortalıkta değil de biraz daha kenarda köşede yapıyorduk vesaire onlar da böyle üstlerini çıkarıp yaparken biz kössede yapıyorduk (gülerek)... antrenman yapıyosun işte evet squat yada eğilecek bir hareket hemen orda işte sette dönüyo direkt böyle (gülerek)” (Yasemin, sporcu).

Araştırmacı: Sen ne yapıyordun böyle durumlarda?

"İste aynadan görünce, şey kenara çekiliyorum ya da birden her şeyi birakıyordum. Böyle ters ters baklyordum, yani profesyonel yapinca (ulusal ve uluslararasi yarışmalara katılmak amacılla) onları sallamıyorduk" (Yasemin, sporcu).

Yasemin'in mekânda üretilen iktidar ilişkilerine karşı geliştirdiği tepki, iktidarın olduğu her yerde bir direniş ya da direniş imkânı (Foucault, 2014: 21) olduğunun bir göstergesi olarak okunabilir.

2. Eril tahakkümün ikiyüzlü anlamları: "Bikini mi, ya nasıl giyeceksin? / Bir gece benimle birlikte olur musun?”

$\mathrm{Bu}$ temada ortaya çıkan temel bulgu, eril tahakkümün, katılımcıların branşlarının bir gerekliliği olarak yarışmalarda giydikleri bikini ve antrenmanda giydikler spor kıyafetleri üzerinden onlara ahlâk dayatması yapma yoluyla kurulduğunu gösterir. Bununla birlikte yarışma ve antrenman fotoğraflarını sosyal medyada paylaşmaları sonucunda cinsel tacize uğramaları bu eril tahakkümün iki yüzlü anlamlarına işaret eder. Bu bağlamda ahlâki beklentileri kadınları ayıplayarak sağlamaya çalışan çifte cinsel ahlâk standardı; kadınların maruz kaldığı tacizi üretme ve meşrulaştırma yolunu seçmektedir. Katılımcıların olumsuz deneyimlerinin ortak noktasını, antrenman esnasında spor salonunda karşılaştıkları rahatsız edici bakışlar ile sosyal medyada paylaştıkları fotoğraf ve videolar hakkında aldıkları yorum ve mesajlar oluşturmaktadır. Örneğin Buket, instagrama bikinili ya da antrenman yaparken koydukları fotoğraflar için "şuna bak orasını burasını açmış gibisinden laflar işte öbür dünyada yanacaksınız gibisinden bakış açıları vardı, işte utanmıyor musunuz ya gibisinden sözler bir sürü düşünceler vardl" diyerek namus kavramının kadınlar tarafından korunmasını bekleyen ataerkil yapıyı ortaya koymaktadır. Yasemin ve Asya'nın deneyimleri de Buket'inkine oldukça benzerdir:

"Orda (instagramda) mesela giyinip bikinili attı̆̆ımız zaman çok iğrenç şeyler yazanlar da oldu. Küfürler var bir sürü argo şeyler var yani. Şunlara bak bir kız böyle yapar mı işte, hep sonra Allah'ı karıştırıyorlar, siz cehennemde böyle yanacaksınız, çok fazla namusla 
alakalı işte söyleyemiyorum, oruspu falan bir sürü şeyler yazanlar oldu...” (Yasemin, sporcu).

“...İ̧ste neden her yerinizi açıyorsunuz, karnınızı açmasanız olmuyor mu, günah değil mi gibi şeyler geliyordu” (Roza, sporcu).

Erkeğe özgürleşme alanları sunan ataerkil düzen, konu kadın olunca aksi yönde bir uçta ilerleyerek kadının kapatılması, baskılanması gerektiği inancını namus kodlarına dayanarak yerine getirir. $\mathrm{Bu}$ bağlamda kadın bedeninin ve cinselliğinin düzenleme ve denetleme yöntemleriyle ataerkil rejim için namus kodları temelinde itaatkârlaştırılması (Kalav, 2015: $34,40)$ modern iktidar teknolojilerinin disipline etme yollarından birisidir.

Katılımcılar için bikini giyme üzerinden geliştiren eleştiriler, sosyal medyada yorum yapmak söz konusu olduğunda şiddetini arttırmış, özellikle instagram sayfalarında paylaştıkları fotoğraflar nedeniyle ayıplama ve küfürle karşılaştıklarını belirtmişlerdir. Fakat burada dikkat çekici nokta katılımcıların ahlâk ve namus gibi kavramlarla denetlenen ve gözetlenen beden aynı zamanda erkekler tarafından taciz edilen bir bedendir. Katılımcılar instagram hesaplarından, erkekler tarafından sık sık taciz içerikli mesajlar aldıklarını vurgulamışlardır.

“...Zaten mesela şimdiki algıda, şöyle ilk başlarda bikinili (fotoğraf) atınca, kimse beğenmiyordu. Mesela hepsi, aaa çok ayıp falan diye... SSimdi bazı erkek ergenus erkekuslar... taş gibi be, üf be, bir sürü şey yazanlar da oluyordu” (Yasemin, sporcu).

"Bikinili fotoğraf atıyosam, bir ara instagram profilim de açıktı değişik değişik insanlar, kalp gönderenler, öpücük gönderenler, değişik değişik yorumlar oluyordu, çok ă̆ır yorumlar atanlar da oluyordu. İște bir gecelik işte bilmem ne kadar falan, bir gece benimle birlikte olur musun, işte şu kadar veririm şöyle böyle diyenler de oluyordu, çok ă̆ır yorumlar da vardl yani" (Asya, sporcu).

"Özellikle daha yeni instagramımın bir tanesini dondurdum, çok sapık var inanılmaz yani artık spora şey gibi bakıyorlar daha böyle cinsel içerikli ... özellikle kalça mesela kalça göğüs yani söyleyemiyorum” (Tuğçe, antrenör).

"Bacak çalıştığım günlerde taytımı daha farklı seçiyordum hani kaslarımı belli etsin diye, izlerken ben de motive olayım diye. Öyle fotoğraflar paylaştı̆̆ımda işte genelde kalça odakl yazlyorlar ya da daha da ileri gidip işte bir geceliğine şu kadar veririm benimle ol diyenler de oldu." (Roza, sporcu).

Cinsellik, kadınlar aleyhine iktidar ilişkilerinin en somut olarak işlediği konulardan biridir. $\mathrm{Bu}$ alıntılarda cinsel tahakküm, erkeklerin kadınlar üzerindeki sistematik iktidarının bir yansımasıdır. Nitekim ataerkil ideolojide kadın bedenini nesneleştirilmesi, bu bedenin cinsel obje olarak görülmesi ile sağlanmaktadır. Bourideu (2014: 35) eril arzuyu, erotikleşmiş tahakküm olarak, sahip olma arzusu olarak yorumlar. Erkeklerin sahip olma arzusunun karşısında ise sahip olunan, edilgen ve pasif konumda yer alan kadın yer alır. Bu durum kadın 
cinselliğini baskılayan erkek cinselliğini meşrulaştıran çifte standartlı bir ideolojiye hizmet eder.

Katılımcılar antrenman yaparken salondaki erkeklerin zaman zaman rahatsız hissedecekleri şekilde baktıklarını ifade etmişlerdir. Yasemin bu konudaki deneyimlerini "antrenman yaplyosun işte evet squat ya da ĕ̌ilecek bir hareket hemen orda işte sette dönüyo direkt böyle bakıyor" şeklindeki sözleriyle açıklamıştır. Abileri de vücut geliştirme ve fitnessçı olan ve onlarla aynı salonda antrenörlük yapan İpek, diğer spor merkezlerinde çalışan kadın antrenörlere göre daha avantajlı olduğunu düşünmektedir. Fakat hem daha güvenli bir ortamda olması hem de tecrübeli bir antrenör olmasına rağmen salondaki erkeklerin bakışlarından rahatsız olmaktadır:

"Açıkçası şimdi abilerimin yanında değil de başka bir spor salonundayım ve spor salonu bildiğin, full time erkek kayniyor. Tek bir bayanım ben. Bir de onlardan daha fazla ăğr giren (ă̆ırlık kaldıran) bir insanım. Bir yandan tedirgin oluyorum, hoca olmama ve tecrübeli olmama rağmen. Ne kadar insanlar tınlamayıp antrenman yapmaya kalksam bile o anki bakış açıları beni sinirlendirebiliyor. Bazen çok tuhaf bakabiliyorlar yani rahatsı edici baklş olabiliyor. Hayranlıkla bir bakış olabiliyor ama şahsen ben çok baklşları sevmediğim için, onlarla diyaloğa girmesem de o anki şey beni etkiliyor yani rahatsızlık veriyor" (Ípek, antrenör).

Yukarıdaki alıntılarda da görüldüğü gibi katılımcıların bikini fitness deneyimleri nedeniyle aldıkları uyarılar, katılımcıların bireysel hak ve özgürlüklerinin sınırını aşmış; şiddet ve taciz üreten bir eylem alanına dönüşmüştür. Fakat diğer tüm katılımcıların aksine antrenör İpek, sosyal medyada taciz edilmediğinin altını çizmiş ve diğer sporcuların bu tarz eylemlere maruz kalmasını onların tacizi çağıran tavırlarına bağlayarak farkında olmadan tacizi meşrulaştırmıştır:

"Şimdi beni rahatsı etmiyorlar, benim de bikinili fotoğraflarım var, benim de klsa şortlarla, yarım atletlerle çekindiğim fotoğraflar var ben kendi resimlerime baktığımda hiçbir kişinin benim yorumumun altına abuk sabuk birşey yazdığını görmüyorum, bir diğer sporculara bakıyorum altına yazılmayan bir yorum kalmıyor."

Araştırmacı: Neyle alakalı sizce bu durum?

"Bu kişinin kendi karakteriyle karşı tarafa verdiği izlenimle alakalı olan bir durum açıkçası onu söyleyim ... Erkekleri tahrik edecek olan olaylar şahsen bana bulunulmadı ama diğer arkadaşların altına yapılan yorumlara baktığımda, çok seksisin, onun dışında beni ara yani bana ulaş dediğinde beraber olalım gibisinden başka tekliflerde bulunan kişiler var. Of yavrum kelimeleri çok fazla meşhurdur ama dediğim gibi bu kişinin herhalde büyük bir ihtimal kendi karakteriyle alakalı. Ne benim fotoğrafimın altında öyle bir yorum var, bir arkadaşım daha var o da milli sporcu onun altındaki yorumda da öyle birşey yok ama bir diğer iki kişiyi takip ediyorum, altında yazılan yorumların haddi hesabı yok o kadar iğrenç kelimeler kullanıllyor, o kadar pis şeylerle ithamlarda bulunuyorlar. Güzel söz de var, kötü 
söz de yer allyor. Tek düşündüğ̈̈m şey neden biz de öyle birşey yokta onlarda var” (Ípek, antrenör).

Foucault'ya (1993) göre, iktidar kurduğu, oluşturduğu birey üzerinden işler (s.86) ve böylelikle bu durum, özünde müdahale, gözetleme ve toplumsal cezalandırma olan iktidar ilişkilerinin zamanla bireyin kendi hakikati haline dönüşmesine (Kalav, 2015: 40) neden olur. İpek'in sözlerinden beden üzerinde iktidarın denetim ve disiplin mekanizmalarının içselleştiridiği; kadın bedeninin cinsel açıdan davetkâr olarak yorumlanmasına kapı araladığı ve tacizin meşrulaştırılmasının önünü açtığı anlaşılmaktadır. Bedenlerin boyun ĕgmesini sağlayan biyo-iktidar (Foucault, 2007: 103) aynı zamanda bir norm oluşturur. Toplumun söylemiş olduğu normu içselleştirme, kendine oto-kontrol uygulayan İpek, kendisini de bir otorite makamı olarak görüp eril tahakkümün en sinsi işlevlerinden birini yerine getirmektedir: Baskı ve denetimin, kadınlar tarafından normun dışında itilen herhangi bir kadın var oluşuna uygulanması. Nitekim Foucault'ya (2012) göre, gözetleyen bir bakış ve bakışın ağırlığını üzerinde hisseden herkes, bakışı oyle icselleştirir ki, sonunda kendini gözleme noktasına varır; böylece herkes kendi üzerinde ve kendine karşı bu gözetlemeyi işletecektir. Böylece iktidar sürekli olarak ve gülünç bir maliyetle işleyececektir (Foucault, 2012: 95).

\section{Belalı Bedenler: "Hem fit olsun, hem bayan olsun, hem kibar olsun"}

Katılımcılar, bu branşı yaparken fazla/aşırı kaslı olmaktan kaçınarak, başka bir deyişle erkekleşmeden yapmaya özen gösterdiklerinin altını çizmiştir. Katılımcıların tamamı için geleneksel kadınlık rollerine uygun bir beden imajı ön plandadır ve onlar için idealize edilen kadın bedeni toplumsal cinsiyet normları ile uyum içindedir: Sıkı fakat erkeksi değil (Buket), çok aşırı kas yapmadım zaten (Yasemin), benim amacım fit ve estetik bir vücut (Roza), kadınlarda fitnessta ince bel büyük kalça (Asya), topluma göre hem fit olsun hem bayan olsun hem kibar olsun (Tuğçe).

Koca (2016: 28), Butler'ın gender trouble kavramına atıfta bulunarak, spordaki kadın bedeninin sıklıkla belalı bir beden olarak sunulduğuna dikkat çeker. $\mathrm{Bu}$ argüman, araştırmamızın bulguları için önemli destek sunmaktadır. Öyle ki katılımcılar için kaslı bedene yönelik toplumsal tepkiler şiddetli olumsuzluklar içerirken, hem toplumun dayattığ hem de kendilerinin içselleştirdiği ideal beden, kadınsı öğerlerle yüklüdür.

Katılımcıların aile ve yakın çevrelerinden aldıkları temel uyarılar erkek gibi olmamaları yönünde ağırlık kazanırken, kadın bedenine dayatılan normun dışındaki kas oranını iğrenç olarak nitelemişlerdir:

"Kadınların tepkileri daha çok, işte ne yapacaksın erkek gibi mi olacaksın işte çok fazla erkek gibi olma kollarını falan omuzlarını biraz daha işte bayan gibi görün gibisindendi" (Asya, sporcu).

"Ya şuna bak iğrenç erkek gibi diyen de vardl, halbuki o kadar abartılı bir durum yoktu. Hani biz o yüzden rahatsız olmuyorduk ya da bakış açısı farklıdır, beğenmek zorunda 
değiller ama saygı duymak zorundalardı, bu çok fazla olmuyordu, işte böyle kı mı olur ay iğrenç midem bulandı gibisinden bir sürü şey yazıyorlardı” (Buket, sporcu).

"Erkekler genel olarak, mesela siz çok iğrençsiniz, abartı bu kas ne iğrenç falan ... bu ne iğrençsiniz siz kendinize ne yapıyorsunuz şöyle bi sürü şey ya o küfürler yakıştırmalar, Kızlar da genelde şöyle mesela atıyorum, bir şeyler, soru soruyorlar mesela, sen bu işi yaptığın için, sonra ama ben böyle aşırı kas istemiyorum, erkek gibi olmayayım, böyle senin gibi olmak istemem" (Yasemin, sporcu).

Katılımcılar için rahatsız edici olan bu tepkilerin onların dünyasındaki anlamı, antrenör Tuğçe'nin sözlerinden anlamak mümkündür. Tuğçe'nin sosyal çevresinden aldığ 1 ilk yorumlar "çocuğum, kızım ne yapmışsın sen abartmışsın sen" şeklinde olurken, ona göre kadın fitness antrenörü olmanın en büyük dezavantajlarından biri "bir topluma girerken yaratık gibi bakılması"dır. Tuğçe kadın ve erkeklerin kendi vücuduna yaptığı yorumların farklılaştığının altını "kadınlar ıyyy diyor ama erkekler de tam tersi kaslı vücut seviyor bayanda" şeklindeki sözleriye çizmiştir. Fakat söz konusu normatif kalıpların dışındaki kas oranı olduğunda hem kadın hem de erkeklerlerin yorumları ortaklaşmaktadır: Aaa sen ne yapmışsın erkek gibi olmuşsun (Tuğçe) erkek gibi olacaksınız deniliyordu (Buket), klasik önyargl, erkek gibi olmamdan korktular (Roza), erkek gibi niye kas yapıyorsun, hiç yakışır mı böyle bir şey (Yasemin), çok erkek gibi olma çok büyüme ne gerek var (Asya).

Cinsiyet farkının toplumsal anlamına göre kadın ve erkek bedeni birbirini dışlayan fiziksel bedene dair söylemlerden beslenir. Dolayısıyla cinsiyet rejiminin inşasında dışlayıcı ve ayıplayıcı pratikler yoluyla kurulur ve bu toplumsal tutum kadınlar tarafından da içselleştirilebilir. Örneğin katılımcıların ideal beden imajını nasıl algıladıklarına baktığımızda onların da çok fazla kaslı olmak ya da erkek gibi olmak istemedikleri anlaşılmaktadır (Roza, Buket, Yasemin, Asya). Örneğin Buket'in "kas isteyen kızlar oluyordu mesela hani daha sık daha biraz daha böyle illaki erkeksi değil yani" şseklindeki ifadesinden ya da Yasemin'in "Benim yaptı̆̆ım gerçekten dikkat çeken büyük kas kütlesi olmadı̆̆ için de erkek gibi göstermiyordum. Yine de bu branş erkeklere adanmış gibi göründüğü için, benim de o kadar kasl olacağım ve bunu istediğim izlenimi oluyordu insanlarda. Illa bu kadar kas yapmak gerekmediğini ve istemediğimi zaten istesem de zor olduğunu, hatta istesemde bu isin çok zor oldugundan saygı duyulacak bir sey olduğunu sürekli açıklamak durumunda kalıyordum” şeklindeki alıntısından da anlaşıldığı gibi ideal kadın bedeni ile kaslı kadın bedeni arasında keskin bir sınır çizilmiştir.

Aşağıdaki alıntılar vücut geliştirme ve fitnessta idealize edilen beden sermayesi ile katılımcıların bu ideal beden formunu içselleştirme pratiklerine dair izler taşımaktadır:

"Benim için ideal vücut kasll ve parçall. Örneğin belirgin omuz başlarl, ince bel ve belirgin karın kası, sıkı bir kalça ve büyük ama abartı değil çünkü bacaklar da kalınlaşıyor ve parçalı bacak kasları ama orantı önemli (gülümseyerek). Orantıdan kastım büyük kalça dar omuz değil ya da tam tersi de değil, 90-60-90 orantısi gibi diyebilirim ... Kadınlar kalça çalıştı̆̆ için tüm vücudu iyi olsa da dikkat edilen nokta hep kalçalar o 
yüzden erkek gibisin diyen arkadaşım olmadı ilgi başka yerdeydi ama deseler hoşuma gitmezdi çünkü benim amacım fit ve estetik bir vücut” (Roza, sporcu).

"Ben tamamen kalça ağırlıklı çalışlyorum (gülümseyerek) en çok gelişmesini istediğim bölge, bunalıma bile girdim. Yani kadınlarda fitnessta ince bel, büyük kalça o zaman kadınlarda iyi olduğunu kanitlyorsun gibi bir şey hocam (gülümseyerek) ... Erkek gibi görünmemden korkuyorlar arkadaşlarım ailem de çok kas yapma falan diye hâlâ söylüyorlar yeter oldu artık diye ama bırakınca da kasın öyle kalacağını sanıyorlar, artık sadece kendim için yapıyorum yani iyi görüneyim, biri benden özel ders alacaksa önce benim iyi olmam önemli, erkek gibi olmayayım diye (gülümseyerek)” (Asya, sporcu).

"Vücut kaygısı olan biriydim, görünüş daha doğrusu. Hani belli başl yerlerin güzel olması her kadının ya da bir bireyin kendini mutlu etmesi için bir sebep aslında. Ne gibi yerler mesela, benim basenlerim baya bi vardl, bacaklarım kalınd, şu anda da öyle ama o zaman ciddi şekilde toparlanmıştı, bunun olabileceğini gördüm aslında ve bu branşı yaptıkça vücudun kendi sınırlarını aştığını gördüm. Hani kendi kafanda kurduğum çizgileri bu branşta aşabiliyordum, böyle birazcık daha buda beni motive ediyordu" (Yasemin, sporcu).

Katılımcılar için bikini fitnessta bedenin kadınsılıkla ilişkilendirilen bölümlerinin özel bir önemi olduğu anlaşılmaktadır. Hacısoftaoğlu ve Bulgu'nun (2012) araştırma bulgularına göre, aerobik egzersiz, ideal kadın bedeni söylemini yeniden üreten bir eyleme olarak iktidarın beden üzerinde kendini gerçekleştirmesine hizmet etmektedir. Bir diğer deyişle, iktidar teknolojilerinin normalleştirme eylemelerinin bir parçasıdır.Bu araştırmanın sonuçları da, bikini fitnessta üretilen kadınlık kimliğinin, ideal bedene ulaşma ile ayrılmaz bir ilişkisi olduğuna işaret etmektedir. Fakat zayıf ve sıkı bir vücudu temsil eden beden ideali, tekilliği yüzünden baskıcıdır (Markula, 1995'ten aktaran Hacısoftaoğlu ve Bulgu, 2012).

Antrenörlük yapan Tuğçe ve İpek ise, seanslarına gelen kadınlar zayıflamak istediklerini fakat kas istemediklerini vurgulamaktadırlar:

"Şey diyorlardı ben spor yapacağım, fit olmak istiyorum, zayıflamak istiyorum ama kas yapmak istemiyorum tepkileri bu... hem fit olsun hem bayan olsun hem kibar olsun düşünceler buna sahip hem de yani bazıları da daha çok şey istiyorlar tamamen manken gibi olsun (gülümseyerek)” (Tuğçe, antrenör).

İpek'in “(erkekler) her zaman için fit kadın istiyor, yani zaylf olsun yani zaylf derken fiziği göbeği olmasın vücudu sıkı olsun güzel bir görüntüsü olsun istiyor” ifadesinden eril normun kodladığı beden idealini görmek mümkündür. Tarihsel ve kültürel olarak erkeklerin domine ettiği sporlarda, kadınlık kimliğininin inşasını alan literatürdeki pek çok çalışma, "kadın kimliği" ile "kadın sporcu" kimliği arasında çatışma ve gerilimlerin yaşandığını göstermektedir. Bu branşlardaki (futbol, boks, güreş, dövüş sporları, vücut geliştirme gibi) kadınlar alanda ötekileştirilmekte, ayrımcılık yaşamakta ve sosyal etiketlenmelerle (lezbiyen, 
erkeksi ve erkek Fatma gibi) karşılaşmaktadırlar. Bu nedenle kadın sporcular, toplumsal cinsiyetlendirilmiş bu alanda var olmak için bazı stratejiler geliştirmektedirler (Brake, 2013; Dessertrain \& Weiss, 1988; Halbert, 1997; Hargreaves; 1997; Kleindienst-Cachay \& Heckemeyer, 2008; Mennesson, 2000; Sisjord \& Kristiansen, 2009; Theberge, 1995; Theberge, 1997). Örneğin kadınların spor ve fiziksel aktiviteye katılımlarının sınırı çok kaslı olmamak ile çizilmektedir. Dolayısıyla uygun görülen ya da görülmeyen kaslılık oranı, toplumun eril kodlarına göre berlirlendiği için gözetim, denetim, disiplin ve içselleştirme gibi yollarla kadın bedeni üzerinde iktidarın işlediği yorumunda bulunabiliriz.

Fitness salonuna gelen çoğu kadının (üyelerin) beden idealine baktığımızda iktidar ile beden arasındaki ilişkiyi görmek mümkündür. Çünkü kadınların arzu ettiği beden; iktidar tarafından idealize edilen bedendir: Zayıf fakat kaslı olmayan beden.

"Genelde bayanlarımızın göbek bölgesi ya da iç bacaklarında ciddi bir anlamda yağlanma meydana geliyor, oralar onlar için gittiğinde onlar için fittir. Yani genelde böyle çok zaylf istemiyorlar, çok zaylf isteyen insan, bazen zaylf geliyor, onda da zayıflama rahatsızlı̆̆ oluyor genel bakıldı̆̆ında"

Araştırmacı: Ne kadar kası olsun istiyor mesela kadınlar?

Kas istemiyorlar

Araştırmact: Ne diyorlar?

Kas olmasın ya, bunu kasa çevirme diyor. Kasın zaten yağdan dönme gibi bir lüksü hiç olmaz, olsaydı bütün bayanlar şu an kaslı olarak gezerdi yani etrafta.

Araştırmacı: Neden kaslı olmak istemiyorlar sizce?

Kötü bir görüntü olduğunu düşünüyorlar” (İpek, antrenör).

Belalı bedenler temasında incelediğimiz ideal beden kurgusu, katılımcıların aynı zamandan kadınlık kimliklerini korumak için geliştirdikleri alanda var olma stratejileridir. Markula (1995) “sıkı fakat biçimli, fit fakat seksi, güçlü fakat ince” söylemiyle kadın bedeni için idealize edilen kültürel anlamının altını çizmiş ve bu beden idealini dayatması nedeniyle egzersizin kadın bedeni üzerindeki baskıcı yönüne dikkat çekmiştir. Araştırmalar, kadınların hâkim söyleme göre şekillenen beden idealine ulaşmak için çaba harcadıklarını göstermektedir ki zayıf, ince ve estetik görünümde olmak -özellikle zayıflama isteği- gibi kadınlık kimliğinin yeniden inşasına dayanan unsurlar bu idealin temel harcını oluşturmaktadır. Böylece kadınların egzersiz ve spor deneyimlerinin önemli bir gerekçesini zayıflama -kilo verme- isteği oluştururken fazla kaslı bir görünüme sahip olmamak dikkat ettikleri bir unsur olarak karşımıza çıkar (George, 2005; Hacısoftaoğlu ve Bulgu, 2012, Krane, 2001; Markland ve Hardy, 1993; Mosewich vd., 2009; Öztürk ve Koca, 2014). Katılımcıların bedenin karın, bel, basen, bacak, kalça gibi kadınsılıkla ve estetikle ilişkilendirilen bölgelerindeki kasları geliştirmeye ya da biçimlendirmeye odaklandıkları ve bunu "erkeksi olmadan” yapmaya özen gösterdikleri anlaşılmaktadır. 
4. Var olma ve mücadele stratejileri: "Özel yaşantımızda her bayan gibi özenliydik ve bunu koruduk, kaybetmedik, nasıl kadınsak öyle kaldık"

Araştırmanın bulgularına göre katılımcılar, erkeksi değerler ve kültürün hâkim olduğu bu alanda erkek gibi olmadan/kadınsılıklarını yitirmeden var olabilmek, maruz kaldıkları taciz içerikli söylem ve pratiklerle mücadele edebilmek ve aileleri ve yakın sosyal çevrelerine bikini fitness sporcusu olduklarını kabul ettirmek adına birtakım stratejiler geliştirmişlerdir.

Katılımcıların kadınlık kimliklerini toplumsal beklentilere göre ispatlamak adına spor ve özel yaşantılarında saç, makyaj ve kıyafetlerine özen gösterdikleri dikkat çekmektedir. Bu noktada kadınlık stratejisi geliştiren sporcular farkında olmadan geleneksel kadın/ideal kadın beklentilerini de karşılamış olmaktadırlar:

"Biz abartmadı̆̆ımız ve öyle (erkek gibi) göründüğümüzü düşünmediğimiz için ekstra bir bakım psikolojisine girmiyorduk. Spor yaptığımız için makyaj vs gibi seyleri önemsiyemiyorduk, spor klyafetlerle geziyorduk ama özel yasantımızda her bayan gibi özenliydik ve bunu koruduk kaybetmedik, nasıl kadınsak öyle kaldık, bu bizden bir şey eksiltmedi çok şey kazandırdı" (Buket, sporcu).

Özellikle erkeklere özgü olarak kodlanan sporlarda kadınlar, heteronormativenin sınırlarını ihlâl etme riski taşımaktadırlar. Bu nedenle spor alanlarında kadınlık kimliklerinden ötürü, gündelik hayatlarında ise sporcu kimliklerinden ötürü olmak suretiyle iki defa ezilmektedirler. Koca (2006), kadın sporu dünyasında, kadın sporcuların kadınlıklarının kutlanması ve değer görmesi yoluyla kadınlığın hegemonik olarak işlendiğini söyler. Buna göre bir erkek alanı olarak görülen spor ortamında yer alan birçok kadın, hegemonik erkekliğin her türlü özelliklerine sahip olan erkek sporcu kimliği altında, kendi sporcu kimliğini oluştururken kadınlığını ön plana çıkardığını, makyaj yaptığını, daha kadınsı kıyafetler giydiğini ve kadınsı davranışlarda bulunduğunu ve diğer taraftan toplumda bu tür davranışlarda bulunmaları beklentisinin var olduğunu da söylemek mümkündür:

"Bakım yapıyordum, burada amaç bunu yaparak kadınlıktan uzaklaşmadığımızı tam aksine ne kadar yakıştı̆̆ımızı ve normal bir şey olduğunu göstermek. Benim yaptığım gerçekten dikkat çeken büyük kas kütlesi olmadı̆̆ için de erkek gibi göstermiyordum. Yine de bu branş erkeklere adanmış gibi göründüğü için benim de o kadar kaslı olacağım ve bunu istediğim izlenimi oluyordu insanlarda. Illla bu kadar kas yapmak gerekmediğini ve istemedigimi, zaten istesem de zor oldugunu hatta istesem de bu işin çok zor olduğundan saygı duyulacak bir sey olduğunu sürekli açılklamak durumunda kalıyordum” (Yasemin, sporcu).

"Şöyle söyleyeyim yani bakım yapıyorum kendime bakıyorum tırnaklarıma saçıma daha çok bayansı giyiniyorum, topuklu giyiniyorum, daha çok bayan olarak giyiniyorum ki görsel olarak yani benim tamamen bayan olduğumu görüp daha çok teşvik etme amaçlı oluyor" (Tuğçe, antrenör). 
"Erkeksi görünmemek için makyaj yaptım ama normalde de yapıyordum, saçım uzundu zaten açık bırakırdım ve vücudumu, hatlarımı belli eden klyafetler giyerdim, başkası kadınsı görsün diye değil tabi ki verdiğim emeği görmek beni mutlu ettiği için (gülümseyerek)” (Roza, sporcu).

Koca’nın (2016: 28) belirttiği gibi, spordaki kadın bedeni çoğunlukla belalı bir beden olarak sunulur çünkü sporcu bedenin özellikleri kadın bedenini içermez. Spor alanında erkek beden sermayesinin (kaslılık ve güç) ve bunu kutsayan eril değerlerin (saldırganlık, rekabet gibi) önemsenmesi, bu sermayenin ve değerlerin dışında kalan sporcu kadınların sporculuk/kadınlık paradoksu yaşamalarına ve var olabilme mücadelelerine bazı stratejiler uygulamalarına neden olabilmektedir. Örneğin kadınların spor ve fiziksel aktiviteye katılımlarının sınırı çok kaslı olmamak ile çizilmektedir. Hacısoftaoğlu ve Bulgu (2012)'nun araştırma sonuçları kadınlar için egzersizin zayıf (ideal/güzel) bedene ulaşmanın yollarından biri olduğunu ortaya koymuş ve bu araştırmada aeorobik egzersize katılan kadınların kas yapmaktan korktukları özellikle ifade edilmiştir. Emir, Karaçam ve Koca (2015) ise kadın boksörler üzerinde yaptıkları araştırmada, kadınların alanda kabul görmek ve var olabilmek için, toplumsal hayatlarında süslenip makyaj yaparak boksör olduklarını belli etmemeye çalıştıklarını, ringin dışında "kadın kalabilmek" için muhafaza stratejisi sergilediklerini göstermektedir. Dolayısıyla bu araştırmalardaki kadınların spor deneyimlerinde fazla kaslı olmamak, geleneksel kadınlık rollerini üretmek gibi bazı stratejileri uyguladıkları anlaşılmaktadır.

Katılımcılarımız için bikini fitnessa başlama fikri öncelikle aileleri tarafından reddedilmiştir. $\mathrm{Bu}$ nedenle ilk olarak ailelerini ikna etme yollarına başvurmuşlar daha sonra ise yaptıkları branşı çevrelerinden gizleme stratejisi kullanmışlardır. Örneğin, Buket, Yasemin ve Roza spora ilk başladıklarında ailelerine bikini giyeceklerini bilinçli olarak söylemediklerinin altını çizmiştir. Bunun dişında çevresindekiler tarafından branşları sorulduğunda bikini fitness yerine atletik fitness ya da bilek güreşi gibi farklı yanıtlar verdiklerini dile getirmişlerdir:

“...birazcık ailemin baskısı altında kaldı̆̆ım için bir ara vazgeçmiştim hani katılmıyordum artık. Sonrası yalan dolanla birazcık daha şey oldu, daha doğrusu yalan değil de birazcık kıvırma diyim mesela şort diyordum işte onu da yapmıştık. Şimdi bunun yanında bir dalı daha vardı atletik fizik diye geçiyordu orda da biraz barfiks çekiyorduk, kürek çekiyorduk vesaire o da bir yarışmaydı. Ben sadece ona gireceğimi söylüyordum ama ona girmişken ona da (bikini fitness) girdim (gülümseyerek)" (Yasemin, sporcu).

“... fazla açmadık spor yapıyorduk, spora gidiyorduk ama bunun ne olduğunu toplum çok fazla bilmiyordu ya da bilek güreşi altında söylüyorduk biz bunu çünkü hem utanıyorduk. İște en başta (ailemize) yalan söylemek zorunda kaldık... (anne antrenmanlara gitmeye izin vermediği için) ben pencereden işte spor çantamı çıkartıyordum kapıdan çıkmaya çalışıyordum” (Buket, sporcu).

\footnotetext{
${ }_{\ddagger}^{\ddagger}$ Koca burada Judith Butler’ın Gender Trouble kavramına atıfta bulunuyor.
} 
"Eskiden hiç kimseye söylemiyorduk fitness yaptığımızl, hiçbir şekilde reklam yapmıyorduk hani böyle düşünecekler diye biz de demek ki nasıl etkilemişlerse ben bile söylemekten utaniyordum, sınıfta ben yarışmaya gittim falan hiçbir şekilde söylemiyordum, hepsine her senelere bilek güreşi diyorduk, işte bişey yapmıyoruz falan böyle çok üstünü kapatıyorduk hatta üniversiteye girince de birazcı ilk dönemlerde böyleydi sonradan işte yapmaya başladıkça açıldık artık, söylemekten hiç çekinmiyorum" (Yasemin, sporcu).

Sporcular için ailelerini ikna etmenin en güçlü söylemi milli takıma girme hedefinde görülmektedir. Nitekim bu katılımcılar için (Buket, Yasemin, Asya ve Roza) milli takım sporcusu olmanın üniversitelerin beden eğitimi bölümlerine girme ya da öğrenci iken millilik bursu alma gibi eğitsel, ekonomik ve saygınlık açısından önemli getirleri olan bir anlamı vardır. "Asıl amacımız milli sporcu olmakt, hem okulumuzu kazanmak hem de burs alıp ailemize yardım etmek amaçlıydl" diyen Buket'e benzer olarak Yasemin'in de "ben sizin için istiyorum ben milli sporcu olmak için sonra devam etmeyecem zaten iste sporu çok seviyorum siz niye arkamda durmuyorsunuz işte vesaire vesaire sürekli böyle savunmalar yapıyordum kendilerine" sözlerinden anlaşıldığı gibi ikna stratejilerinde somut sportif başarı kriteri (milli olmak) son derece önemli bir işlev görmüştür. Nitekim bu başarı kriterinin hem aileler üzerinde hem de komşular üzerinde oldukça önemli bir dönüşüm yarattığı Yasemin'in “işte milli sporcu olduktan sonra işte yarışmada derece yapınca bu sefer hani elde kupayla girince o mahalleye, o eve herkesin bakış açısı değişti vay be falan aldınız işte birşeyler kazandınız mı şöyle böyle helal olsun yaptınız vesaire, bu sefer tam tersi oldu” ve Asya'nın "tam tersi destekliyolar şu an milli sporcu bursu da aldı̆̆ım için de, maaşı var işse mahallededen de olumlu tepkiler alıyorum" ifadelerinden anlaşılmaktadır.

Ipek ise akrabalarından aldıkları ayıplama içerikli yorumlar nedeniyle ailesinin etkisini arttıran tepkisine karşı özellikle babası ile mücadele ederek yaptığı branşı kabul ettirdiğini ifade etmiştir:

“...onlara bir şeyleri kabullendirdim ama ben onların sözünü dinleyip kapanmaya başlasaydım olay olmaya devam edecekti o yüzden üstlerine gide gide aileme tamamen kabul ettire ettire bunlar oldu. Babam açıkçası hiç kabul etmedi yarışmaya girişimi, o bikiniyi tesadüf eseri telefonda gördü. Sen bunu giyersen beni öldür mezara götür dedi, çok istiyorsan mezara girebilirsin dedim çünkü ben bu bikiniyi giyip de ben bu yarışmaya gireceğim. Ĕğer sen beni dedim, klyafetimle namusumu ölçüyorsan şimdi gidip kendini atabilirsin dedim. Adam tabi baya bir kötü oldu filan (gülüşmeler) ondan sonra yavaş yavaş bir ikna etme çabalarımız oldu yavaş yavaş kabullendi” (İpek, antrenör).

Erkek ağırlıklı bir alanda spor yaparken rahatsız edici bakışlarla karşılaştıklarında Asya'nın "kesinlikle terk etmiyorum (antrenman alanını) tam tersi antrenmanımı yapmaya devam ediyorum. Ya da antrenman yaparken ĕ̆er mide falan çalışıyosam tam tersi midemi açıp da bakabiliyorum" ifadesinden ve Buket'in "ben de ona karşı gözlerinin içine bakarak ters bir bakış atıyordum" şeklindeki sözlerinden de anlaşıldığı gibi katılımcıların direniş ve karşı koyma stratejisi uyguladığı anlaşılmaktadır. 
Katılımcıların instagram hesaplarından aldıkları yorumlarla nasıl mücadele ettikleri sorulduğunda ise çoğunlukla görmezden gelme stratejisi uyguladıkları anlaşılmıştır. Roza, "onları (yorumları) eskisi kadar takmamaya başladım, mesaj yazanların sildim, özelden mesaj gönderenleri kabul etmedim mesajını, zaten sürekli yazan sürekli yazan olduysa onları da engelledim” derken Tuğçe, "özellikle daha yeni instagramımın bir tanesini dondurdum çok sapık var inanılmaz yani artık spora şey gibi bakıyorlar daha böyle cinsel içerikli" sözleriyle bu tacizlerle nasıl başa çıktıklarını anlatmıştır.

\section{SONUÇ VE ÖNERILER}

Spor alanlarında kadın bedeni, iktidar ilişkilerinin sürdürülmesi ya da egemen söyleme meydan okuması bakımından çarpıcı bir anlama sahiptir. Nitekim spor, kadınların onlara atfedilen ince-narin-hassas gibi formların dışına çıkmalarını sağlaması bakımından bir direniş alanı oluşturabildiği gibi toplumsal cinsiyet rejiminin yeniden inşasını sağlaması bakımından kadın bedeni üzerinde kurulan bir denetim aracına dönüşebilir.

Kaslı olmayı erkeğin biyolojik özelliğine atfetme ve kaslı bedeni kadınsılıkla ilişkilendirmeme üzerine inşa edilen toplumsal cinsiyet rejimi, kadın bedeni üzerinde onların geleneksel rollerine göre şekillenen kalıplarla bir takım denetim mekanizmaları oluşturmaktadır. Araştırmamızın bulguları kadın bedeni üzerindeki eril tahakküm ve disiplinci iktidar pratiklerinin farklı ve çoklu bağlamlarda oluştuğunu göstermektedir. Katılımcılarımızın aldığı temel uyarı, erkek gibi olmadan, erkekleşmeden ve çok kaslı olmadan alanda var olmalarına yöneliktir. Koca'nın (2016: 28) da altını çizdiği gibi, spor alanında erkek beden sermayesinin (kaslılık ve fiziksel güç) ve bunu kutlayan eril değerlerin (saldırganlık, rekabet gibi) önemsenmesi, bu sermayenin ve değerlerin dışında kalan sporcu kadınların sporculuk/kadınlık paradoksu yaşamalarına ve var olabilme mücadelerinde bazı stratejiler uygulamalarına neden olabilmektedir. Heteroseksüel kadınlığa uymama cinsiyetçi ve heteroseksist bir ayrım getirmektedir ve bu ayrımdan kaçmak için sporcu kadınlar kadınlıklarını vurgulamaya çalışmaktadırlar (Koca, 2006). Bizim çalışmamız açısından da benzer bir çelişki söz konusudur. Öyle ki katılımcılar fazla kaslı olmamaları ve erkek gibi görünmemeleri konusunda sık sık uyarılar almış, bu uyarı ve beklentileri içselleştirmek ve toplumsal cinsiyet normlarını yeniden üretmek suretiyle muhafaza stratejisi (Emir, Karaçam ve Koca, 2015) geliştirmişlerdir. Dolayısıyla çok kaslı olmadan, erkekleşmeden, estetikliğini ve kadınsılığını yitirmeden; diğer bir deyişle idealize edilen kadınlık normlarının dışına çıkmadan alanda var oldukları anlaşılmaktadır.

Düzeltme ve normalleştirme işlevlerini, namus ve ahlâk gibi kodlar üzerinden kurmaya çalışan iktidar mekanizması, katılımcılarımızın bedenleti üzerinde denetim kurmuş ve spor deneyimlerini baskılamıştır. Sporcuların bikini giymelerinden duyulan kolektif bir ataerkil rahatsızlık söz konusudur. Bourdieu'ya (2014: 22) göre toplumsal düzen, amacı, üzerine temellendirdiği eril tahakkümü tasdik etmek olan devasa bir sembolik makina gibi işler. Çalışmamızın sonuçlarına göre de bu tahakküm katılımcılarımızın aileleri, akrabaları, kız ve erkek arkadaşları ya da sevgilileri tarafindan kurulmuştur. Fakat bu eril tahakküm aynı zamanda iki yüzlüdür. Çünkü bir yandan toplumsal ahlâkı kadınları kapalı (!) tutarak sağlayacağını düşünürken diğer yandan toplumsal kalıplara bedenleri (bikini giyme) ve başarı 
hedeflerinde kararlı bir şekilde yürüyerek (ulusal ve uluslararası yarışmalara katılma; dereceler elde etme) karşı koyan kadınlar, direniş imkânının her yerdeliğgini hatırlatmaktadır.

Spora ve egzersize katılım kadının hem fiziksel hem de psikolojik olarak güçlenmesine hizmet edebilir, kadınlar kendi fiziksel becerilerini test edebilir, kişisel bir başarı duygusu geliştirebilir ve kendi bedenlerini kendileri kontrol edebilirler. Bu bağlamda sporun kadınların özgürlügünde bir ajan olabilme potansiyeli, kadınların bu alandaki ezilme deneyimlerinden değil, kendi bedenlerini güçlü ve eril egemenlikten bağımsız/özgür olduğu deneyimlerinden kaynaklanmaktadır (Koca ve Bulgu, 2005). Kadın bedeninin özgürlüğünün sınırları eril tahakküme göre belirlenir kadınların ikincil konumu kültürel ve toplumsal olarak onaylanır ise, kadının nesneleşmesi ve tacize açık hale gelmesi sonucu ile karşılaşırız. Dolayısıyla özgürlügün sınırları eril tahakküme göre değil eril tahakküme rağmen çizilmeli ve korunmasının zorunluluğu toplumsal onaydan geçmelidir. Bunun için başta spor kurumlarında olmak üzere tüm toplumsal kurumlarda kadınlar için spor deneyimlerinin onları güçlendirici etkisinin dikkate alındığı toplumsal cinsiyet eşitliğine yönelik politikalar üretilmelidir.

\section{KAYNAKLAR}

Akgündüz, G. Ö. (2013). Foucault'da iktidar ve beden ilişkisi. Akademik Bakış Dergisi, 38, 1-16.

Bilgin, R. (2015). Tüketim kültüründe kadın bedeninin cinsel kurgu olarak konumlandırılması ve sunumu. International Journal of Social Science, 36, 309-329.

Bilgin, R. (2016). Geleneksel ve modern toplumda kadın bedeni ve cinselliği. Fırat Üniversitesi Sosyal Bilimler Dergisi, 26(1), 219-243.

Bourdieu, P. (2014). Eril tahakküm. (B. Yılmaz Çev.). İstanbul: Bağlam Yayıncılık.

Brake, D. L. (2013). Wrestling with gender: Constructing masculinity by refusing to wrestle women. Nevada Law Journal, 13, 486-532.

Chalabaev, A., Sarrazin, P., Fontayne, P., Boiché, J., \& Clément-Guillotin, C. (2013). The influence of sex stereotypes and gender roles on participation and performance in sport and exercise: Review and future directions. Psychology of Sport and Exercise, 14, 136-144.

Chimot, C., \& Louveau, C. (2010). Becoming a man while playing a female sport: The construction of masculine identity in boys doing rhythmic gymnastics. International Review for the Sociology of Sport, 13, 1-21.

Dedeoğlu, A. Ö., ve Savasçı, İ. (2005). Tüketim kültüründe beden güzelliği ve yemek yeme arzuları: kadınların tüketim pratiklerine yansıması. Ege Academic Review, 5(1), 77-87.

Demez, G. (2012). Medyada yeni sağlık anlayışları ve kadın bedeninin temsili. Uluslararası İnsan Bilimleri Dergisi, 9(1), 512-532.

Desertrain, G. S., \& Weiss, M. R. (1988). Being female and athletic: A cause for conflict? Sex Roles, 18(9), 567-582.

Doğan, S. Y. (2010). Tüketim kültüründe kadın bedeninin idealize edilmesine yönelik kadın algılamaları ve tüketim davranışlarıyla ilişkisi. Selçuk Üniversitesi Sosyal Bilimler Enstitüsü Dergisi, 23, 51-59.

Emir, E. Karaçam, M. Ş., ve Koca, C. (2016). Kadın boksörler: Boks ringinde ve ringin dışında sürekli eldiven giymek. Spor Bilimleri Dergisi Hacettepe, 26(4), 136-153. 
Ersöz, A. G. (2010). Tüketim toplumunda "sıfır beden" söylemi: Neden ve sonuçları üzerine sosyolojik bir değerlendirme. Edebiyat Fakültesi Dergisi, 27(2), 37-53.

Foucault, M. (2012). İktidarın Gözü. Seçme Yazılar 4. I. Ergüden (Çev.). (3. Basım) İstanbul: Ayrıntı Yayınları.

Foucault, M. (2014). Özne ve İktidar.Seçme Yazılar 2. I. Ergüden, O., \& Akınbay (Çev.). (4. Basım) İstanbul: Ayrıntı Yayınları.

Foucault, M. (1993). Ders özetleri 1970-1982. S. Hilav (Çev.). (2. Basım). İstanbul: Yapı Kredi Yayınları.

Foucault, M. (2007). Cinselliğin Tarihi. H.U. Tanrı̈ver (Çev.). (2. Basım). İstanbul: Ayrıntı Yayınları.

George, M. (2005). Making sense of muscle: The body experiences of collegiate women athletes. Sociological inquiry, 75(3), 317-345.

Hacısoftaoğlu, İ. (2005). Fiziksel etkinliklerin kadınların bedenlerinin ve toplumsal kimliklerinin yapılanmasındaki işlevi. Yüksek Lisans Tezi. Hacettepe Üniversitesi. Sağlık Bilimleri Enstitüsü.

Hacısoftaoğlu, İ., ve Bulgu, N. (2012). Kadınlar ve egzersiz: Aerobik egzersizin çatışmalı anlamları. Spor Bilimleri Dergisi Hacettepe, 23(4), 177-194.

Halbert, C. (1997). Tough enough and woman enough: Stereotypes, discrimination, and impression management among women professional boxers. Journal of Sport and Social Issues, 21(1), 7-36.

Hargreaves, J. (1997). Women's boxing and related activities: Introducing images and meanings. Body \& Society, 3(4), 33-49.

İnceoğlu, Y. ve Kar, A. (2010). Yeni güzellik ikonları: İnsan bedeninin özgürlüğü mü, mahkumiyeti mi? Y. İnceoğlu ve A. Kar (Der.) Dişilik, güzellik ve şiddet sarmalında kadın ve bedeni içinde (s. 65-90). İstanbul: Ayrıntı Yayınları.

Kalav, A. (2015). Değişen ve dönüşen sosyal bir olgu olarak namus ve toplumsal cinsiyet. Yüksek Lisans Tezi. Akdeniz Üniversitesi Sosyal Bilimler Enstitüsü.

Karaçam, M.Ş. (2015). Vücut geliştirme alanında erkeklik kimliğinin inşasında besin desteği kullanımının yeri. Yüksek Lisans Tezi. Hacettepe Üniversitesi. Sağlık Bilimleri Enstitüsü.

Karaçam, M.Ş., ve Koca, C. (2014). Egzersiz alanında besin desteği kullanımına sosyolojik açıdan bir bakış: Abi ben yeni başladım, benim almama gerek var mı? Toplum ve Hekim, 29(5), 366-380.

Kavasoğlu, İ., ve Yaşar, M. (2016). Toplumsal cinsiyet normlarının dışındaki sporcular. Spor Bilimleri Dergisi Hacettepe, 27(3), 118-132.

Kaylı, D. (2009). Feminist eleştirel yaklaşımlarda özgürleşme ve kadın bedeni. Yüksek Lisans Tezi. Ege Üniversitesi. Sosyal Bilimler Enstitüsü.

Kesim, S., ve Kar, A. (2010). Plastik cerrahi, “Tanrım beni baştan yarat!..” metaforunu mümkün kılabilir mi? Y. İnceoğlu ve A. Kar (Der.). Dişilik, güzellik ve şiddet sarmalında kadın ve bedeni içinde (s. 173-196). İstanbul: Ayrıntı Yayinları.

Kleindienst-Cachay, C., \& Heckemeyer, K. (2008). Women in male domains of sport. International Journal of Eastern Sports ve Physical Education, 6 (1), 14-37.

Koca, C. (2006). Beden eğitimi ve spor alanında toplumsal cinsiyet ilişkileri. Spor Bilimleri Dergisi Hacettepe, 17 (2): 81-99.

Koca, C. (2016). Cinsiyetlendirilmiş bir alan olarak spor. C. Koca (Ed.). Sporun toplumsal cinsiyet halleri içinde (s. 1837). Ankara: Spor Yayınevi.

Koca, C., ve Bulgu, N. (2005). Spor ve toplumsal cinsiyet: Genel bir bakış. Toplum ve Bilim, 103, $163-181$. 
Koca, C., ve Demirhan, G. (2005). Beden eğitimi ve spor alanında toplumsal cinsiyetin yeniden üretimi. Spor Bilimleri Dergisi Hacettepe, 16 (4), 200-228.

Koca, C., Öztürk P., ve Arslan B. (2012). Kadınların spor ve fiziksel aktiviteye katılımı. Ankara: Kadınlar İçin Spor ve Fiziksel Aktivite Derneği.

Koivula, N. (2001). Perceived characteristics of sports categorized as gender-neutral, feminine and masculine. Journal of Sport Behavior, 24 (4), 377-393.

Köse, H. (2011). Tüketim toplumunda bir "sosyal beden” kurgusu olarak kadın. Selçuk Üniversitesi İletişim Fakültesi Akademik Dergisi, 6(4), 76-89.

Köse, H. (2016). Bourdieu düşüncesinde tahakküm-itaat ilişkisi ve sosyo-politik beden. Illef Dergisi, 3(2), 173-199.

Krane, V. (2001). We can be athletic and feminine, but do we want to? Challenging hegemonic femininity in women's sport. Quest, 53(1), 115-133.

Kula Demir, N. K., \& Yiğit, Z. (2013). Reklam fotoğraflarında kadın bedeninin değişimi. Turkish Studies, 8(6), 459-472.

Kümbetoğlu, B. (2015). Sosyolojide ve antropolojide niteliksel yöntem ve araştırma. (4. Bask1). İstanbul: Bağlam Yayınları.

Lefebvre, H. (2016). Mekânın üretimi. (4. Baskı). I.Ergüden (Çev.). İstanbul: Sel Yayıncılık.

Markland, D. \& Hardy, L. (1993). The exercise motivations inventory: Preliminary development and validity of a measure of individuals' reasons for participation in regular physical exercise. Personality and Individual Differences, 15(3), 289-296.

Markula, P. (1995). Firm but shapely, fit but sexy, strong but thin: The postmodern aerobicizing female bodies. Sociology of Sport Journal, 12(4), 424-453.

Matteo, S. (1986). The effect of sex and gender-schematic processing on sport participation. Sex Roles, 15(7-8), 417-432.

Mayring, P. (2011). Nitel sosyal araştırmaya giriş. A. Gümüş \& M.S. Durgun (Çev.). Ankara: BilgeSu Yayıncılık.

Mennesson, C. (2000). Hard women and soft women The social construction of identities among female boxers. International Review for the Sociology of Sport, 35 (1), 21-33.

Mosewich, A. D., Vangool, A. B., Kowalski, K. C., \& McHugh, T. L. F. (2009). Exploring women track and field athletes' meanings of muscularity. Journal of applied sport psychology, 21(1), 99-115.

Ozansoy, N. (2012). Tüketim toplumunda güzellik imajının üretimi. Yüksek Lisans Tezi, Ege Üniversitesi, Soyal Bilimler Enstitüsü, İzmir.

Öztürk, P. (2016). Sporda toplumsal cinsiyet çalışmalarının tarihsel seyri. C. Koca (Ed.). Sporun toplumsal cinsiyet halleri içinde (s. 38- 55). Ankara: Spor Yayınevi.

Öztürk, P. ve Koca, C. (2014). Egzersiz ve performans sporunda beden politikaları. Toplum ve Hekim, 29(5), 333-343.

Patton, M.Q. (2014). Nitel Araştırma ve değerlendirme yöntemleri. M.Bütün ve S.B. Demir (Ed.). Ankara: Pegem.

Riemer, B. A. \& Visio, M. E. (2003). Gender typing of sports: an investigation of Metheny's classification. Research Quarterly for Exercise ve Sport, 74, 193-204.

Sarup, M. (2004). Postyapısalcılık ve Postmodernizm. A. Güçlü (Çev.). (2. Basım). Ankara: Bilim ve Sanat.

Sisjord, M. K. \& Kristiansen, E. (2009). Elite women wrestlers' muscles: physical strength and a social burden. International Review for the Sociology of Sport, 44(2-3), 231-246. 
Talimciler, A. (2015). Sporun sosyolojisi sosyolojinin sporu. (2. Basım). İstanbul: Bağlam Yayınc1lık.

Theberge, N. (1995). Gender, sport, and the construction of community: A case study from women's ice hockey. Sociology of Sport Journal, 12(4), 389-402.

Theberge, N. (1997). It's part of the game physicality and the production of gender in women's hockey. Gender \& Society, 11(1), 69-87.

Timurturkan, M. (2009). İktidarın nesnesi olarak beden. Yüksek Lisans Tezi. Akdeniz Üniversitesi, Sosyal Bilimler Enstitüsü.

Topaloğlu, H. (2010). Gölgedeki bedenler: Bedenin inşa sürecinde toplumsalın etkileri. Alternatif Politika, 2(3), $251-276$.

User, İ. (2010). Biyoteknolojiler ve kadın bedeni. Y. İnceoğlu ve A. Kar (Der.). Dişilik, güzellik ve şiddet sarmalında kadın ve bedeni içinde (s. 133-169). İstanbul: Ayrıntı Yayınları. 